\title{
Çocuklarda Benlik Düzenleme ve Benlik Tükenmesi: Benlik Düzenlemenin Gelişimi, Sonuçları ve Sınırlı Kaynak Modeli
}

\author{
Tuğçe Göğer \\ Selçuk Üniversitesi \\ Aile Danışmanlığı ve Eğitimi Anabilim Dalı \\ tugcegoger@outlook.com
}

\author{
Gökhan Arslantürk \\ Selçuk Üniversitesi, Edebiyat Fakültesi \\ Psikoloji Bölümü \\ gokhan_arslanturk@hotmail.com
}

\section{Öz}

Etkili benlik düzenleme; okul başarısı, kaliteli sosyal ilişkiler, psikolojik ve fiziksel sağlık gibi yaşamın birçok alanındaki olumlu sonuçlar açısından oldukça önemlidir. Bununla birlikte benlik düzenleme kapasitesi sınırsız değildir. Art arda gelen öz denetim etkinlikleri benlik düzenleme başarısızlıklarına yol açabilir. Sınırlı güç modeline göre benlik düzenleme etkinlikleri sınırlı bir kaynaktan beslenir ve bu kaynak geçici olarak tükenebilir. Kurama göre ego tükenmesi olarak adlandırılan bu durum öz denetim başarısızlıklarının nedenidir. Bu derleme çalışmasında benlik düzenleme ve sınırlı kaynak modeli gelişimsel açıdan ele alınmıştır. Benlik düzenlemenin gelişimi, çocuklardaki benlik düzenleme başarısızlıkları ve öz denetim becerisinin geliştirilmesi üzerine yazın gözden geçirilmiştir. Ayrıca sınırlı güç modeline ilişkin tartışmalara değinilmiş ve gelecekteki çalışmalar için bir bakış açısı sunulmuştur.

Anahtar Kelimeler: Benlik düzenleme, öz denetim, benlik tükenmesi, sınırlı güç modeli.

\section{Self-Regulation and Ego Depletion in Children: Development, Consequences of Self-Regulation and Limited Resource Model}

\begin{abstract}
Effective self-regulation is crucial for positive outcomes in many areas of life including school success, quality social relationships, psychological and physical health. However, capacity of self-regulation is not unlimited. Sequential self-control activities can lead to selfregulation failures. According to the limited strength model, self-regulation activities are based on a limited source and this resource may be temporarily depleted. This situation, which is called ego depletion according to the theory, is the cause of self-control failures. In this review study, self-regulation and limited strength model were addressed from a developmental perspective. The literature on the development of self-regulation, selfregulation failures in children, and the improvement of self-regulation skills has been reviewed. In addition, debates on the limited strength model were mentioned and a perspective for future studies is presented.
\end{abstract}

Keywords: Self-regulation, self-control, ego depletion, limited strength model. 


\section{GİRIŞ}

Gündelik hayat hemen her gün farklı düzeylerde öneme sahip kararlar almayı, seçimler yapmayı ya da irade sergilemeyi gerektiren durumlar barındırmaktadır. Gerek bir toplumun ya da topluluğun parçası olmanın beraberinde getirdiği birtakım kurallara, normlara ya da rollere uygun davranma zorunluluğu gerekse kendi yararımız açısından bazı istek ve dürtülerin önceliğinin düzenlenmesi, duygu ve davranışlarımız üzerinde denetim sahibi olmayı gerekli kılmaktadır. Koşullarımızı iyileştirmek, bir bütünün uyumlu parçası olabilmek ya da bazı zararlı durumlarla karşılaşmamak için insanlar hayvanlara göre içgüdüleri dışında kendi tepkileri üzerinde denetim gösterebilme, içsel durumunu düzenleme ve davranışlarının seyrini değiştirebilme kapasitesine sahiptir (Baumeister, 2003, Bronson, 2019). Bununla birlikte insana davranışlarında esneklik ve karmaşıklık kazandıran ve yaşamın birçok alanındaki olumlu sonuçlarla yakından ilişkili olan bu benlik düzenleme kapasitesi sınırsız ve sonsuz değildir (Baumeister, 2003).

Benlik düzenleme başarısızlıklarının nedenini anlamak amacıyla yola çıkan araştırmacıların olağan şüpheli olarak bu sözü edilen kapasitenin sinırlılı̆̆ı üzerine odaklanması benlik düzenleme yazınına ve sonraki araştırmalara yön vermiştir. Sınırlı kaynak modeline göre (Muraven ve Baumeister, 2000; Muraven, Tice ve Baumeister, 1998) bireyler yukarıda değinilen amaçlar doğrultusunda öz denetim sergiledikçe benlik düzenleme kaynaklarında bir tükenme yaşanır. Benlik tükenmesi (ego depletion) olarak adlandırılan bu durum sonraki öz denetim etkinliklerinin başarısızlıkla sonuçlanmasına yol açar.

Benlik düzenleme kapasitesinin sınırlı bir kaynağa dayandığına ve birbirini izleyen öz denetim çabalarının bu kaynakta tükenmeye yol açtığına ilişkin kuramsal yaklaşım benlik düzenleme yazınında oldukça rağbet görmesine ve alanda yürütülen görgül çalışmalara kuramsal dayanak oluşturmasına karşın gelişimsel bakış açısı ile konuyu ele alan çalışmalar yeterli değildir. Özellikle benlik tükenmesi ile ilgili Türkiye'de yapılan çalışmaların sayısı yok denecek kadar azdır.

$\mathrm{Bu}$ çalışmada benlik düzenleme ve benlik tükenmesi alanındaki çalışmalar ışığında çocuklarda benlik tükenmesi ve benlik düzenleme kapasitesine dikkat çekmek amaçlanmıştır. Bunun da ötesine Türkiye'de benlik tükenmesi ve benlik düzenleme arasındaki ilişkinin ortaya konması konusunda yürütülecek çalışmalar için bir çıkış noktası oluşturmak ve gelecekteki çalışmalara kaynak sunmak amacıyla ilgili yazındaki kuram ve araştırma bulguları derlenmiştir. Bu doğrultuda çocuklarda benlik düzenleme ve benlik tükenmesini anlamak için öncelikle benlik düzenleme kavramına odaklanmak gereklidir.

\section{Benlik Düzenleme Nedir?}

Değişen zamanın ve koşulların beraberinde bireye hedeflerine ulaşmakta yol gösterici olan; belirli mekanizmalar ve destekleyici becerilerin otomatik veya planlı kullanımı ile duygu, düşünce, davranış ve dikkatin düzenlenmesini gerektiren bir dizi işlemsel süreç benlik düzenlemesi olarak tanımlanabilir (Karoly, 1993). Alandaki birçok çalışmanın ortak noktası olarak benlik düzenlemenin, hedefler belirlemek ve belirlenen hedefe ulaşmak için davranışların yönlendirilmesi süreci olduğu söylenebilir (Boekaerts, Pintrich ve Zeidner, 2000). Bir diğer ifadeyle benlik düzenlemesi, bireyin karşılaştığ ${ }_{1}$ belirli durumların sosyal ya da bilişsel gereksinimlerine uyum sağlayabilmek ya da amaçlanan bir işi başarmak gibi hedefleri için duygu, düşünce ve davranışlarını oluşturabilmesi, izleyebilmesi, 
değiştirebilmesini kapsayacak şekilde düzenlemesini, yani duygu ve davranışlarını planlı bir şekilde yönetebilmesini ifade etmektedir (Berger, Kofman, Livneh ve Henik, 2007; Zimmerman, 2000). Watson ve Tharp (2014) da benzer şekilde benlik düzenlemesini duygu, düşünce, davranış ve dürtülerin birtakım ilkeler doğrultusunda kontrol edilmesi ve yönlendirilmesi olarak tanımlamıştır. İlgili çalışmalara bakıldığında genellikle duygular, düşünceler, dürtüler ve görev performansı olmak üzere dört alandaki denetimin benlik düzenlemesi olarak incelendiği görülmektedir (Baumeister, 2003).

Alan yazınını incelediğimizde benlik düzenleme ve öz denetim kavramının bir arada kullanılmakla birlikte bazen birbirlerinin yerine de kullanıldığını görebiliriz. Bununla birlikte bazı araştırmacılar benlik düzenleme ve öz denetimin anlamlarının yakın olsa da aslında aralarında farklılıklar olduğu görüşündedir. Örneğin, Baumeister ve Alquist'e göre (2009) benlik düzenleme, öz denetime nazaran çok daha geniş bir anlamı ifade eder; hatta benlik düzenleme öz denetimi de içine almaktadır. Öz denetim benlik düzenlemenin bilinçli ve çaba gerektiren biçimlerini ifade ederken, daha geniş anlama sahip benlik düzenlemenin öz denetim dişında bilinçsiz süreçleri de kapsadığı düşünülmektedir. Örneğin vücut sıcaklığını ayarlama gibi kişinin bilinçli kontrol etmediği eylemler de kendini düzenleme olarak değerlendirilir (Baumeister, Vohs ve Tice, 2007). Bu makalede ise söz konusu iki kavram aynı anlamda ele alınmıştır. Öz denetim, öz düzenleme ya da kendini düzenleme olarak da karşımıza çıkan benlik düzenlemesi, hedeflerimizin ve sonuçlarının uyuşmazlıklarına verdiğimiz kararlı ve hızlı tepkiler olarak ele alınır. Ayrıca istenmeyen dürtüleri durdurabilmeyi, yok sayabilmeyi ve değiştirebilmeyi içeren benlik düzenlemesi, insan yaşamındaki olumlu sonuçlarla ilişkilidir (Tangney, Baumeister ve Boone, 2004). Sağlıklı psikolojik işleyişin özü olan bu kavram; duygu, düşünce ve davranışları kontrol edebilmeyi içerir (Hoyle, 2010).

Tüm bu tanımlar bir arada düşünüldüğünde benlik düzenlemesi özetle; koşullar değişse de bireyin belirlediği amaca ulaşmasında yol boyu bireye yardımcı olan, düşünce, duygu, davranış, dikkat ve dürtü gibi farklı bileşenlerin süreç boyunca planlanmasını, düzenlenmesini, değiştirilmesini ve yönlendirilmesini barındıran karmaşık bir bütündür.

\section{Benlik Düzenlemenin Gelişimi}

Çocuklarda benlik düzenleme becerisini gözlemlemek için kullanılan tipik deneylerden biri marşmelov testidir (Mischel, Shoda ve Peake, 1988). Bu deney düzeni özellikle hazzı ertelemenin özgün bir göstergesidir. Beş yaşındaki bir çocuğa önünde duran bir marşmelovu (bir tür yumuşak şekerleme) yemek ya da bir süre bekledikten sonra iki adet marşmelova sahip olmak arasında bir seçim şansı sunulur. Deneyci odadan çıktıktan sonra dönene kadar marşmelovu yemeden bekleyen çocuk ikinci bir marşmelova sahip olacaktır. Diğer bir ifadeyle çocuk şimdiki bir ödülden vazgeçer, hazzı geciktirebilirse potansiyel daha büyük bir hazza erişebilecektir ve bu öz denetim gerektirir. Peki bu öz denetim becerisinin ortaya çıkışı nasıl bir süreç izler?

Benlik düzenleme gelişimi genetik etkileri düşündügümüzde tahminimizden çok daha erken başlayan bir süreci ifade etmektedir. Benlik düzenleme kapasitesindeki farklılıklar ya da öz denetim düzeyi ve buna bağlı olarak ortaya çıtığı düşünülen bir takım davranış sorunları üzerinde bazı genetik etkilerin olduğu düşünülmektedir (Barnes, Boutwell, Beaver ve Gibson, 2013). 
Genetik etkilerin ötesinde en ilkel biçimleri ile benlik düzenleyici davranışlar yaşamın ilk yıllarından başlayarak ilerleyen yaşlara değin gözlenebilen bir gelişimsel seyir izlemektedir. Kendini yatıştırıı bir takım temel davranışlarla bebeklikten başlayan kendini düzenlemenin gelişim sürecini ergenliğe değin gözlemlemek ve erken dönemde benlik düzenleme becerilerindeki bireysel farklılıklara tanık olmak mümkündür (Berger ve ark., 2007; Bronson, 2019; Kopp, 1982; 1989). Kopp (1982) benlik düzenlemenin gelişimini doğumla beraber başlatmış ve 5 aşamalı olarak sınıflandırmıştır:

Doğumdan sonraki ilk 2-3 ayı kapsayan dönem olan nörofizyolojik evrede, benlik düzenlemeden çok önce bebeğin, davranışlarını refleksif hareketler ve uyarılmalar ile düzenlediği (parmak emmek için kullandığı el-ağız hareketi gibi) görülür. Bu evredeki bu tip davranışlar bebekteki düzenleme mekanizmalarına işarettir (Kopp, 1982). Bronson (2019) da bunu destekler nitelikte bebeğin bu dönemde nesneleri ve yüzleri tanımaya başladığını, alıştığı rutinlerin başlayacağına dair belirtiler gördüğünde sakinleştiğini ifade ederek bu dönemi bilişsel düzenlemenin başlangıcı olarak belirtmiştir.

İkinci dönem olan duyumotor evre 3.aydan başlayarak 9-12. aylara kadar sürer. Daha sonraki dönemlere temel teşkil eden bu dönemde bebek bir nesneye ulaşma, onu tutma veya onunla oynama gibi davranışlarda bulunur ancak bu dönem tam bir farkındalık dönemi sayılamaz (Kopp, 1982). Ayrıca 3-8 aylık dönemde olumlu ve olumsuz duygular ile baş etme süreci olarak tanımlanan duygu düzenlemesinin gelişimi için bakım verenin rolü önemlidir (Kopp, 1989).

Bakım veren ile sosyal etkileşimin yoğun olduğu kontrol evresi 9-12. aylarda başlar ve 18. ayda biter. Bebeğin davranışlarında ve kurduğu iletişimde farkındalığının olması göze çarpar ama ebeveynlerin koyduğu kurallar dönem boyunca içselleştirilmemiştir; onların basit emirlerine ve isteklerine uyma anlamında bir farkındalık söz konusudur. Bakım veren ile etkileşimin yoğun olduğu bu dönem benlik düzenlemesinin gelişimde önemli bir geçiştir (Kopp, 1982) çünkü çevresel uyaranları çocuğun anlamlandırabilmesi noktasında ailesi etkilidir. Etkinlikler, oyunlar, çocuğa sunulan deneyimler ve kurulan ilişki süreçte bebeğin benlik düzenleme gelişiminde olumlu etki yapar (Emre, Tarkoçin, Temiz ve Ulutaş, 2019).

24. ayla birlikte ortaya çıkan öz denetim eoresinde dışardan izleyici, denetleyici yoksa da çocuk sosyal beklentilere göre davranışta bulunmaya başladığı gözlenebilir. Çocuğun nerede oynaması gerektiği ve hangi nesnelerle oynayabileceği; bir arkadaşında, akrabasında ya da bir mağazada ne yapılacağı ile ilgili bilgisi vardır (Kopp, 1982).

İlk 4 evrenin ardından 3 yaşında çocuk, benlik düzenleme evresine geçer (Kopp, 1982). Erken yaşlarda gelişmeye başlayan benlik düzenleme ilk evreden son evreye kadar diştan denetimli ve ebeveyn uyumlu davranıştan içten denetimli davranışa doğru kademeli bir geçiş sergilemektedir. Feng, Hooper ve Jia (2017) da Kopp'un 1982'de ortaya koyduğu gelişim aşamalarını inceledikleri araştırmalarında bunu doğrulayan sonuçlara ulaşmışlardır. Araştırmada yürümeye başlayan çocukların sürekli izleme altında dış taleplere uyduğu, okul öncesindeki çocukların sınırlı denetim ile isteyerek ve kuralları kabul ederek uygun davranışlar sergilediği, anaokulu çocuklarının ise kendi davranışlarını kendisinin düzenleyebildiği görülmüştür. Zamanla çocuk, içselleştirdiği davranışları otorite olmadan farklı ortamlarda ve durumlarda da gösterir duruma gelmektedir. Bu evrede çocuk sahip olduğu benlik düzenleme becerisini değişen koşullara da uyarlayabilir (Zimmerman, 2000). Diğer bir deyişle bu gelişimsel seyir, yukarıda değinilen bilinçli öz denetim ve bilinçsiz 
kendini düzenlemeyi de kapsayan benlik düzenleme arasındaki ayrımı teyit etmektedir. Basitçe refleksif bir kendini düzenleme ile başlayan gelişim, tedricen bilinçli öz denetim becerisinin kazanılmasına ve daha sonra değişen durumlara göre esnek bir şekilde kendini uyarlayarak benlik düzenleme becerisinin edinimine uzanan bir süreç izler.

\section{Çeşitli Kuramlar Açısından Benlik Düzenlemenin Gelişimi}

Gelişimsel bakış açısıyla benlik düzenlemeye karşılık gelen bir takım kapasite ve beceriler geçtĭgimiz yüzyılın başlarından itibaren çeşitli psikoloji kuramlarında kendine yer bulmuştur. Örneğin, Freud ile başlayan psikanalitik bakış açısına göre çocukların en temel gelişim görevi güçlü bir ego geliştirmektir. Ego geliştikçe benlik düzenleme de artar. Nitekim Freud benlik düzenlemeyi id ve süperego arasında savaşan egonun mücadelesi olarak ele alır (Bronson, 2019). Çünkü birey çocuklukta hazzı ertelemeyi düşünebildiğinde, zihinsel temsiller olarak canlandırabildiğinde dürtüsel eylemlerinin dolayısı ile idin isteklerinin önüne geçebilir. Bunu da id ve süperego arasında arabulucu olan ego ile sağlayabilir (Mischel, Shoda ve Rodriguez, 1989).

Davranış kontrolünde çevreye ve pekiştirmeye vurgu yapan davranışçı bakış açısına göre ise benlik düzenleme, kişinin hoşuna giden durumu pekiştirici olarak değerlendirmesi, bunu artırmak için davranışta bulunması ya da hoşuna gitmeyen durumu cezalandırıcı olarak değerlendirmesi, bunu azaltmak için davranışta bulunması olarak açılanır. Bu sürecin alt süreçleri kendini izleme, kendini değerlendirme ve kendini pekiştirmeyi içerir ve alt süreçler sayesinde benlik düzenleme farklı şekillerde teşvik edilir (Mace, Belfiore ve Shea, 1989). Çocuğun ödülü göreceli olarak değerlendirilmesi, hedefi seçmesi, etkili yönergeleri kullanarak davranışını düzenlemesi davranış̧̧lara göre benlik düzenlemedir. Gerçek ödüllerle edinilen deneyimler; planlı ve plansız eğitimler, öğretimler benlik düzenlemeyi etkiler. Zamanla çocuk kendi kendine pekiştirme yapmayı öğrenerek benlik düzenleme becerisi kazanır, yani benlik düzenlemesi öğrenilmiştir (Bronson, 2019).

Piaget ise öz denetimi zekâ ve duygulanım olarak 2 alanda açıklamıştır. Zekâ, niyet ve düşüncelerin kasıtlı yönü ve problem çözme eylemiyken; duygulanım, kişinin istek ve duygularının iradesi ve kontrolüdür. Bu iki alan, çocuk düşünce ve eylemlerini kontrol ettikçe birlikte gelişir. Gelişim sürecinde ise yetişkinlerin ve akranların farklı rolleri vardır ancak akranla kurulan etkileşim iş birliğine dayalı olduğundan çok daha ön plandadır. Piaget, öz denetimin gelişiminde akran etkileşiminin üzerinde durur (Piaget 1959, 1964, 1968' den akt; Fox ve Riconscente, 2008).

Sosyal Bilişsel Kuram'ın benlik düzenlemesini sıkça ele aldığını ve kuramın öncüsü Bandura' nın birçok araştırmasının ana konusu olduğunu söylemek mümkündür. Bandura (1991); insan duygu, düşünce, davranış ve motivasyonunun sadece dış kaynaklarla şekillenmediğini; kişinin sosyal etkenlerle şekillenen benlik düzenleme sürecinin de etkili olduğunu vurgulamıştır. Bandura, benlik düzenlemeyi kişinin kendi davranışının nedenlerini ve sonuçlarını izlemesi, kişisel standartları ve çevresel koşullara ilişkin davranışını yargılaması ve duygusal açıdan kendini değerlendirmesi gibi bazı bilişsel işlevleri içeren çok yönlü bir durum olarak açıklamıştır. Bir diğer sosyal bilişsel kuramcı Zimmerman (2000), sosyal bilişsel açıdan benlik düzenlemeyi kişisel hedeflere ulaşmak için planlı, döngüsel ve kendiliğinden olan eylemler olarak tanımlamıştır. Döngüsel olmasını önceki performans geri bildirimlerinin sonraki performansta kullanılması olarak açılamıştır. Öz denetim döngüsünü öngörü, performans ve öz yansıtma olarak 3 aşamaya ayıran Zimmerman (2000) davranış, çevre ve kişi etkileşimi doğrultusunda davranışsal

SEFAD, 2021; (45): 375-400 
benlik düzenleme, çevresel benlik düzenleme ve örtülü benlik düzenleme olmak üzere üçlü bir benlik düzenleme yapısı tanımlamıştır (Zimmerman, 1989). Ayrıca sosyal bilişsel kuramcılara göre bu denetim mekanizmasında öz-yeterlilik oldukça önemlidir (Bandura, 1991; Bandura, Caprara, Barbaranelli, Gerbino ve Pastorelli 2003; Zimmerman, 1989; Zimmerman, 2000). Öz-yeterlilik, kişinin hedeflenen bir davranışı yapabilmek ya da bir işi başarmak noktasındaki kendi kapasitesine ilişkin inançlarıdır (Bandura, 1994, 1997; Zimmerman, 2000). Kişisel yeterlilik beklentilerinin oluşmasında etkili olan öz-yeterlilik (Bandura, 1978; Bandura, 1983) sayesinde insanlar sahip oldukları bilgi kaynaklarını işler, düzenler, bir araya getirir ve bu doğrultuda hangi davranışa ne kadar çaba harcayacağını belirler (Bandura, 1977). Bandura' ya (1995) göre öz-yeterlilik, kişinin karşılaşabileceği durumlarda gereken davranışı düzenleyip gerçekleştirebileceğine olan inanç ile nitelenir. Sahip olduğu mekanizmalar ile davranış kontrolü sağlayan birey için bu inanç; düşünme, hissetme, kendini motive etme ve davranış biçimini belirlemede kritik öneme sahiptir.

Zihinsel süreci bilgisayar metaforu ile açıklayan bilgi işleme bakış açısına göre insanlar bilgi işlemcileridir (Mayer, 1996). Küçük yaşlarda bilgileri kodlar, düzenler ve işlemlerinde geri bildirimleri kullanır; etkileşimlerle git gide daha organize bir bilişsel sürece sahip olur. Bu yaklaşım, benlik düzenleme süreçlerini insanların kendi kendine düzenlediklerini kabul eder (Bronson, 2019). Bilgi işleme, benlik düzenlemeye önemli katkılar sağlasa da bireysel farklılıkları açıklamak yönünden sınırlıdır (Hoyle, 2010).

Vygotsky'e göre ise benlik düzenleme kavramı dikkat, düşünce ve eylemlerin istemli kontrol biçimini almasıdır. Öz denetim gelişiminde yetişkinler ve okul etkilidir. Temelde sosyal etkileşim dil aracıllğı ile sağlanır ve dil temelli sosyal etkileşimin içselleştirilmesi ile öz denetim de gelişim gösterir. Yani dil öz denetimin gelişmesinde çok önemlidir. Bununla birlikte oyun da bu gelişimde etkindir (Fox ve Riconscente, 2008).

\section{Benlik Düzenlemenin Gelişimi için Önemli Etkenler}

Benlik düzenlemenin gelişiminde ilk olarak kalıtsal özelliklerin etkili olduğu yapılan ikiz çalışmaları ile gösterilmiştir. 12 ve 14 yaşındaki ikizlerle yürütülen boylamsal bir çalışmada genetik etmenlerin her iki yaşta da benlik düzenlemeyi etkilediği görülmüştür (Anokhin, Golosheykin, Grant ve Heath, 2011). İkizlerle yürütülen başka bir araştırmada da genetik etmenlerin düşük benlik düzenleme becerisindeki varyansı yüzde 52 ile 64 arasında açıkladığı bulunmuştur (Beaver, Wright, DeLisi ve Vaughn, 2008). Bununla birlikte benlik düzenlemenin biyolojik yönü çevresel etmenler kadar araştırılmamıştır.

Çocuk, benlik düzenleme kapasitesine biyolojik olarak sahip olsa bile benlik düzenleme becerisinin gelişiminin hızla devam ettiği unutulmamalıdır. Çocuğun toplumsal yaşamındaki sosyal ilişkilerini düzenlemesinde ve gelişimi boyunca devam eden öğrenme süreçlerinde kilit rol alan bu beceri, erken çocuklukta desteklenmelidir. Bu minvalde, benlik düzenlemenin gelişiminde sosyal etkileşim önemlidir (Orange, 1999). Çocuk ilk eğitimini aileden alır ve ilk sosyal ağı da ailesidir. Bu bakımdan da ebeveynler çocuğa doğru rol model olarak benlik düzenlemesinin gelişimine olumlu katkı sağlamalıdır (Astarlar, 2019). Rol model olmada ebeveynlerin çocukları ile kurduğu iletişimin kalitesi ve ebeveyn tutumu gibi etkenler de etkili görünmektedir. Moilanen, Padilla-Walker ve Blaacker'ın (2018) ergenler ve ebeveynleri ile yaptıkları araştırmada olumlu duygular ve olumlu iletişim gibi unsurlarla ilişkili olan düzenleyici destekleyici ebeveynliğin benlik düzenleme ile ilişkili olabileceğini bulmuştur. Başka bir araştırmada ise otoriter ve aşırı koruyucu ebeveyn tutumları ile benlik düzenleme arasında negatif bir ilişki bulunmuştur (Temiz, 2019). Uykan 
ve Akkaynak (2019) da otoriter ebeveynliğin arttıkça benlik düzenleme becerisinin azaldığına ilişkin sonuçlar bildirmektedir. Bununla uyumlu olarak demokratik ebeveynlik arttıkça benlik düzenlemenin artıyor olması çalışmanın bir diğer sonucudur. Hatta daha kapsamlı düşünüldüğünde ebeveyn-çocuk ilişki kalitesi, benlik düzenleme ve obeziteyi önleme ile ilgili olan bir derlemede, olumlu ebeveyn-çocuk ilişkilerinin çocukluk obezitesinde önleyici olabileceği belirtilmiş ve benlik düzenleme becerisi düşük çocukların aşırı obez ve kilolu olabileceğine işaret edilmiştir (Anderson ve Keim, 2016).

Benlik düzenlemenin alt boyutları ile bağlanma stilleri arasındaki ilişkiyi konu alan araştırmalar, güvenli bağlanmaya sahip çocukların güvensiz bağlanmaya sahip olanlara göre daha etkili benlik düzenleme becerilerini kullandığına işaret etmektedir (Bayındır ve Ural, 2019; Baysal ve Özgenel, 2019). Anne baba tutumları ve bağlanma stili ile ilgili önerilen bir modelde (Zeinali, Sharifi, Enayati, Asgari ve Pasha, 2011) otoriter ve ihmalkâr ebeveynlik tutumu güvensiz bağlanma ve düşük benlik düzenleme ile eşleştirilirken demokratik ve izin verici ebeveyn tutumu güvenli bağlanma ve yüksek benlik düzenleme ile eşleştirilmiştir. Ayrıca düşük benlik düzenlemenin daha fazla bağımlılık yapıcı madde kullanımına neden olacağı varsayılmış ve araştırma neticesinde model doğrulanmıştır.

Mizaç ve benlik düzenleme becerisi karşılıklı olarak birbirini etkiler. Ebeveynlerin de çocuklarına karşı kullandığı tutum zor mizaçla ilişkili olan düşük benlik düzenleme becerisine karşı koruyucu bir etkendir (Wills, DuHamel ve Vaccaro, 1995). Duygusallık gibi mizaç örüntülerinin gelişimi benlik düzenleme becerisinden etkilenir (Denissen, van Aken, Penke ve Wood, 2013; Chen ve Schmidt, 2015). Düşük düzeyde duygusal tepkisellik, canlılık, daha fazla dayanıklılık gibi olumlu mizaç özelliklerine sahip kişiler benlik düzenleme becerilerini etkili kullanır (Nęcka, Korona-Golec, Hlawacz, Nowak ve GruszkaGosiewska, 2019). Duygusal dengesizlik ise düşük benlik düzenleme ile ilişkilidir (Bukhtawer, Muhammad ve Iqbal, 2014). Daha yüksek benlik düzenleme becerisi duygusal mizacın bir yönü olarak duygu deneyimine ve duygu ifade edebilmeye katkı sağlar (Kim ve Kochanska, 2012).

Benlik düzenlemenin gelişiminde etkili olan başka bir etken ise dil becerileridir. Türkiye'de yapılan bir çalışmada da okul öncesi çocukların benlik düzenleme becerilerinin alıcı ve ifade edici dil beceri puanlarıyla ilişkili olduğu görülmektedir (Karakurt, 2019). Frick, Forslund ve Brocki'nin (2019) 4 yaşına kadar olan çocuklarla yürüttükleri boylamsal çalışmada da benlik düzenlemenin gelişiminde anne duyarlılığının ve alıcı dilin önemli olabileceğine dair sonuçlara ulaşmışlardır. Bu bulgular Vygotsky bakış açısına da destek olarak yorumlanabilir.

Benlik düzenleme gelişiminde çocuğa fırsatlar sunan diğer bir etken ise oyundur. Oyun oynamak, çocukluk hayatının ayrılmaz bir bütünüdür ve farklı gelişim alanlarında olumlu etkiler yarattığı kabul görmektedir. Çocuk, oyun oynarken farklı yaşam rollerini ve becerilerini deneme imkânı yakalar. Ayrıca odaklanma, seçim yapma, planlama, etkinliği başlatma ve durdurma gibi değişik düzenleme mekanizmalarını barındırması yönüyle oyun düzenleyici bir işleve sahiptir ve benlik düzenleme gibi temel kapasitelerin gelişiminde etkilidir (Foley, 2017). Bu açıklamaya paralel olarak Whitebread, Coltman, Jameson ve Lander (2009) da süreci çocuğun kontrol ettiği ve seçimleri çocuğun yaptığı oyun oynamanın planlı öğrenme, problem çözebilme ve yaratıcılık içeren akademik becerilerin gelişiminde önemli olan üst bilişsel gelişim ve benlik düzenleme gelişiminde etkili olduğunu belirtmişlerdir. 25 Yeni Zelandalı okul öncesi eğitim alan zor çocuk (ebeveynleri tarafından 
yönetme bakımından zor olarak nitelendirilen yani benlik düzenlemesi düşük çocuklar) ve ailelerinin katılımı ile yürütülen bir çalışmada dikkat, davranış, dürtü ve duygu kontrolü için oyunlar içeren bir müdahale programı 5 haftalık süre boyunca uygulanmış ve aileler günlük olarak belirli oyunları çocukları ile oynamışlardır. Araştırmanın sonucunda elde edilen veriler, çocukların benlik düzenlemesinde gelişme olduğunu göstermiştir (Healey ve Halperin, 2015). Türkiye'de 149 çocuk ile yapılan başka bir araştırmada ise akran ile oynanan oyunun benlik düzenleme ve matematik becerisini desteklediği sonucuna ulaşılmıştır (İvrendi, 2016).

Savina'ya göre (2014) oyun oynamak, çocukların benlik düzenleme becerisine şu şekillerde katkı sağlar:

- Çocuk, oyunda uyması gereken kurallar ile yaşamdaki kurallara da uymayı öğrenir ve bu sayede dürtüsel davranışlarını engeller.

- Çocuk, oyun oynarken aynı zamanda özgürdür; oyunu dilediği gibi düzenler, bu sayede kendi davranışlarını yönlendirmeyi öğrenir.

- Oyun oynamak, içten denetimli davranış oluşumunda etkilidir.

- Oyun esnasında çocuk sürekli konuşma halindedir, bu sözel etkinlik benlik düzenlemeye katkı sağlar.

Başlı başına akranlarla kurulan ilişkilerin çocuk benlik düzenleme becerisini desteklediği söylenebilir. Anaokuluna devam eden çocuklarla yürütülen ve benlik düzenleme becerileri ile akran ilişkileri arasındaki ilişkiyi inceleyen bir araştırma sonuçları davranış düzenleme puanı arttıkça sosyallik puanının da arttığını göstermektedir. Diğer bir ifadeyle benlik düzenleme becerileri ile akran ilişkileri arasında anlamlı bir ilişki söz konusudur (Pazarbaşı ve Cantez, 2019). Bu minvalde dikkate alınacak bir diğer bulgu da benlik düzenleme becerisi arttıkça akran zorbalığına maruz kalmanın azalmasıdır (İleri, 2019).

Benlik düzenlemenin gelişiminde cinsiyetin rolü de araştırmalara konu olmuştur ancak alan yazında bu konudaki bulgular tartı̧̧malıdır. Bazı çalışmalar kızların benlik düzenleme becerisini erkeklere göre yüksek olarak bildirirken (Atmaca, 2019; Dağgül, 2016; Kochanska, Coy ve Murray, 2001; Tuzcuoğlu, Efe-Azkeskin, İlçi-Küsmüş ve Cengiz, 2019) erkeklerin benlik düzenleme becerisinin daha yüksek bulunduğu çalışmalar da mevcuttur (Kara, 2014). Bazı araştırmalar ise anlamlı bir fark olmadığını bildirmektedir (Mercan, 2019; Temiz, 2019; Uykan ve Akkaynak, 2019).

\section{Çocuklarda Benlik Düzenlemenin Sonuçları}

Benlik düzenleme becerisi insan hayatının birçok alanını doğrudan etkiler. Öyle ki Zimmerman (2000) bu beceriyi insanın sahip olduğu en önemli nitelik olarak görmektedir. $\mathrm{Bu}$ becerinin gelişiminde çocukluk dönemi kritik olduğundan okul öncesi çocuklarla yapılmış olan çalışmalar oldukça fazladır ve birçok araştırma tarafından bu becerisi yüksek olan çocuklar olumlu özelliklerle ilişkilendirilmiştir. Örneğin yukarıda değinilen marşmelov testinde başarılı olan yani hazzı erteleyebilen çocuklar boylamsal çalışmalardan elde edilen bulgulara göre birçok alanda daha olumlu sonuçlar elde etmektedirler (Mischel ve ark., 1988; Mischel ve Ark., 1989; Rawn ve Vohs, 2006).

Benlik düzenleme becerisi yüksek olan çocuklar davranışlarının sorumluluğunu alabilirler. Düşük benlik düzenleme becerisine sahip çocuklar ise okulda ve sosyal 
yaşantısında yetersizlik duygusu ile birlikte bazı sorunlarla karşılaşabilirler (Atmaca, 2019). Ayrıca bu çocuklar, davranış problemleri göstermeye yatkındır çünkü çocukluktaki benlik düzenleme becerisi ile bir takım davranış sorunları arasında ilişki vardır (Tozduman-Yaralı ve Güngör-Aytar, 2017). Yine ergenlik dönemindeki problemli davranışlar da çocukluktaki benlik düzenleme ile ilişkilidir (Sohn, Buchanan, Heo ve Lee, 2019).

Sosyal yaşantı kadar akademik yaşantıda da benlik düzenleme becerisi oldukça kritiktir. Çocuklukta sağlıklı bir benlik düzenleme edinmenin erken yaşlardan itibaren sosyal ve akademik birçok olumlu özelliği öngördüğü ve bu anlamda sağlıklı bir gelişim sürecinin habercisi olduğu bilinmektedir (McClelland ve Cameron, 2011). Benlik düzenleme, erken dönemdeki okula hazır bulunuşluk (Adagideli, 2018; Bayındır ve Biber, 2019; Schmitt, McClelland, Tominey ve Acock, 2015; Tekin, 2018; Ursache, Blair ve Raver, 2012; Willis ve Dinehart, 2014) ve uzun vadede çocuğun akademik başarısında etkili olmaktadır (Gestsdottir ve ark., 2014; McClelland ve Wanless, 2012; Sop, 2016). Yüksek benlik düzenleme becerisi olan çocukların akademik benlik saygısı (Mercan, 2019), okula uyum becerileri (Şepitci-Sarıbaş ve Gültekin-Akduman, 2019) ve akademik öz-yeterlilikleri (AldanKarademir, Deveci ve Çaylı, 2018) de yüksektir. Örneğin Türkiye' de 4. sınıf öğrencileri ile yürütülen bir araştırmada benlik düzenleme ve matematik başarısı arasında ilişki bulunmuştur (Demir ve Budak, 2016). Akademik başarıda etkili olan okul olgunluğunun da benlik düzenleme ile ilişkili olduğu bildirilmektedir (Şamlı, 2019). 16-18 yaş arası ergenlerle yapılan bir çalışmada (Napolitano, Hoff, Ming, Tu ve Rounds, 2020) yüksek benlik düzenleme becerisi olan ergenlerin gelecekteki kariyerlerini veya öncelikli seçecekleri meslekleri bildirme oranı daha yüksek bulunmuştur. Araştırmacılara göre kariyer gelişimi uzun dönemli hedef belirleme ve motivasyon gerektiren bir süreçle ilgili olduğundan bunu benlik düzenleme becerisi yüksek olan ergenler başarabilir ve ergenlik kariyer planlama basamağında kritik bir dönemdir. Okul hayatında olduğu gibi iş hayatında da benlik düzenleme becerisi etkindir. Benlik düzenleme meslekteki mevkiyi ve maaşı yordar (Converse, Pathak, DePaul-Haddock, Gotlib ve Merbedone, 2012). Hatta iş arama davranışının altında yatan motivasyonel süreç de benlik düzenleme ile ilişkilidir (Liu, Wang, Liao ve Shi, 2014; Kanfer, Wanberg ve Kantrowitz, 2001).

Benlik düzenleme becerisi yüksek olan çocukların kendilerine ilişkin daha olumlu düşüncelere yani olumlu benlik algısına sahip oldukları görülmektedir (Tuzcuoğlu ve ark., 2019). Düşük benlik düzenlemesinin problemli internet kullanımı (Alçay, 2019), akıllı telefon bağımlılığı (Mazılı, 2019) yüksek sınav kaygısı (Özen,2016), düşük öz-yeterlilik (HosseinZiyae-Sabonchi, 2019), sosyal medya bağımlılığı (Selçuk, 2019) gibi bir dizi olumsuz sonuçla ilişkili olduğu da araştırmalarla desteklenmiştir. Genç yetişkinlikte ve gençlerde ölüm ve yaralanmalara yol açan birçok riskli davranış da benlik düzenleme ile ilişkilidir (Zimmerman, 2000). Benlik düzenleme becerisi gelişmiş insanların, sigara içme, yeme problemleri, aile içi şiddet, suça karışma gibi istenmeyen davranışları gösterme olasılıkları düşüktür (Baumeister, 2018). Ayrıca, benlik düzenleme romantik ilişkilerde gerekli olan fedakârlık gösterebilme becerisinde de etkilidir (Bunt ve Hazelwood, 2017). Yüksek benlik düzenleme becerisine sahip kişiler romantik ilişkilerinde kişisel çıkarlarına göre hareket etme eğiliminde olmadıklarından benlik düzenleme becerisi sağlıklı ve uzun vadeli ilişkilere sahip olmada önemli bir rol oynar (Hofmann, Finkel ve Fitzsimons, 2015).

SEFAD, 2021; (45): 375-400 


\section{Benlik Tükenmesi}

Benlik düzenleme bir güce ya da kaynağa dayanan bir etkinlik midir, bir bilişsel süreç midir yoksa bir yetenek mi? Bu sorular aslında bu alandaki temel üç farklı yaklaşımı yansıtmaktadır. Hangisinin doğru olduğu üzerine eğilen araştırmalar ise ardıl benlik düzenleme etkinliklerindeki performans değişimi üzerinden sonuca varmaya çalışmaktadırlar. Eğer bu bir bilişsel süreç ise arka arkaya yapılan iki öz denetim girişiminde artan bir performans olmalıdır zira zihin önceki görevde hazırlanmıştır ve bir takım bilişsel modüller erişilebilir hale gelmiştir. Eğer bir beceri ise bir görevden diğerine hızlı bir değişim olmayacağından performans aynı kalmalıdır. Zira becerilerin gelişimi daha uzun soluklu etkinliklere dayalıdır. Ĕ̆er bir güç ya da kaynak söz konusu ise bu tükenebilir bir şeydir ve bir performanstan diğerine bir azalma gözlenmelidir. Konu hakkında yapılan çalışmalar da tam olarak bu üçüncü yaklaşımı desteklemekte görünmektedir (Baumeister, 2003).

Benlik düzenlemenin neredeyse hayatımızın her alanında etkin olması araştırmacıları bu özellik ile ilgili farklı konuların açığa kavuşması için çalışmaya itmiştir. Benlik düzenlemeye ilişkin en temel ilgi odaklarından biri de benlik düzenleme başarısızlıkları ve benlik düzenleme kapasitesinin geliştirilip geliştirilemeyeceği üzerinedir. Bu noktada en bilinen yaklaşım ise tüm benlik düzenleme etkinliklerinin ortak sınırlı bir kaynağa dayandığı ve bu kaynağın geçici olarak tükenebileceği yani bir ego tükenmesi durumu yaşanabileceği varsayımına dayanan benlik düzenleme gücü (a strength model of selfregulation) ya da sınırlı kaynak modelidir (Baumeister, Bratslavsky, Muraven ve Tice, 1998; Baumeister ve Heatherton, 1996; Baumeister ve ark., 2007).

Görünüşte birbiri ile alakasız olan benlik düzenleme eylemlerinin ortak bir kaynağa bağlı olduğu ve bu kaynağın da sınırlı olduğu ve benlik düzenlemenin farklı eylemlerde kullanılması ile kaynakta tükenme olacağı tezi 1990'lı yıllarda Baumeister ve arkadaşları tarafından gündeme gelmiştir (Baumeister ve ark., 1998; Baumeister ve Heatherton, 1996; Baumeister ve ark., 2007). Baumeister ve arkadaşlarının yaptı̆̆ı deneyde (1998) çikolata yerine turp yiyen katılımcılar sonrasında sinir bozucu bir bulmaca görevinde çabuk pes etmiştir. Çikolataya direnme ve onu izleyen benlik düzenleme gerektiren bulmaca görevinin birbirini etkiliyor gibi görünmesi, durumun ortak bir kaynak ile ilgili olabileceğini düşündürmüştür. Onlara göre benlik, bir güç ya da enerjiye bağlı olarak işlev görür ve ilk benlik düzenleme gerektiren eylemde bu güç ya da enerjinin kullanılması sınırlı olan kaynağın bir kısmını tüketir ve bireyin sonraki benlik düzenleme performansında düşüş gözlenir (Muraven, Tice, Baumeister, 1998; Baumeister, 2002, 2003). Sınırlı olan benlik kaynağının tükenmesi ilgili yazında benlik kaynaklarında tükenme olarak yerini almıştır. Bahsedilen bu tükenme korkunç boyutta bir tükenme değildir, benlik bir taraftan kaynaklarını korur; yani çok önemli bir durum olmadıkça gerçek bir tükenme olmaz ama çok önemli bir durum varsa kaynaklarını daha fazla tüketir (Baumeister, 2002) ve yaşanılan tükenme de geçici bir süreçtir (Baumeister, Gailliot, DeWall ve Oaten, 2006). Ayrıca sınırlı olan benlik düzenleme kapasitesi artırılabilir veya azaltılabilir (Baumeister ve Heatherton, 1996). Bu anlamda zaman içinde geliştirilebilir bir beceri olarak dile getirmek de tümüyle yanlış görünmemektedir.

Baumeister ve arkadaşları sınırlı benlik kaynağının artıılması veya azaltılabilmesinin daha iyi anlaşılabilmesi için kas metaforunu kullanmışlardır (Baumeister, 2003; Baumeister ve ark., 2006; Baumeister ve ark., 2007). Egzersiz yapmak kasın gelişmişliğine göre belirli bir zaman sonra kası yorar ve performansta bir bozulma meydana gelir. Benlik kaynakları bir 
kasa benzetildiğinde de benlik tükenmesi olarak karşımıza çıkan durum budur. Benlik düzenleme gerektiren bir alanda güç tüketildiğinde sonraki eylem de buna bağlı olarak değişir. Yorgunluk, aşırı çaba gösterme ve stres gibi etkenler de kaynağın tükenmesinde etkilidir (Baumeister ve Heatherton, 1996). Kasın gelişmişliği ise düzenli egzersize bağlıdır, düzenli egzersizle kaslar güçlenir. Tıpkı bunun gibi benlik kaynakları da zamanla geliştirilebilir (Baumeister, 2003).

Baumeister ve arkadaşları başta glikozun benlik kaynağının önemli bir bileşeni olduğunu iddia etmişlerdir. Birçok davranışın benlik düzenleme ile şekillendiğini ve benlik düzenlemenin de kandaki glikozu kullandığını varsaymışlardır (Gailliot ve ark., 2007; Gailliot ve Baumeister, 2007). Baumeister'in öğrencisi Gailliot ve arkadaşlarının (2007) yaptığı deneysel çalışmada katılımcıların benlik düzenleme sonrasında kandaki glikoz seviyelerinin düştüğü ve beraberinde benlik düzenleme becerilerinde de düşüş olduğu gözlenmiştir. Sonrasında ise katılımcılara glikozlu içecek verilmiş ve verilen görevde benlik düzenleme becerisinde artış olmuştur. Ancak bu konu tartışmalıdır ve sorgulanmıştır. Nitekim bazı araştırmalara göre kandaki glikoz seviyesi ve benlik düzenleme arasında ilişki yoktur (Dang, 2016; Lange ve Eggert, 2014; Lange, Seer, Rapior, Rose ve Eggert, 2014; Lange, 2015; Molden ve ark., 2012; Zahn, Tug, Wenzel, Simon ve Kubiak, 2016). Baumeister da kitabının önsözünde çalışmalarda olan tutarsızlıklar nedeniyle artık glikozun benlik düzenleme üzerindeki etkisine inanmadıklarını belirtmiştir (Baumeister, 2018).

Diğer yandan benlik tükenmesi yaklaşımını gözden geçirmeye teşvik eden araştırmalara da rastlanmaktadır (bkz. Inzlicht ve Schmeichel, 2012). Baumeister ve Vohs (2007), kişinin bir hedefe yönelik olan benlik düzenleme becerisini kullanmada sahip olduğu enerjiyi belirlediği hedefe yönlendirebilmesinin motivasyon gerektirdiğini; ayrıca motivasyonun, benlik kaynaklarındaki tükenmeyi geçici olarak telafi edebileceğini belirtmişlerdir. Yeterince motive olan bireylerin benlik tükenmesinin etkisini telafi edebilmesini (Muraven ve Slessareva, 2003) Inzlicht ve Schmeichel (2012) sözü edilen tükenmenin bir kaynak eksikliğinin değil, motivasyon eksikliğinin sonucu olarak yorumlamaktadırlar. Ayrıca, yorgunluk gibi benlik düzenleme becerisini olumsuz etkileyen durumlarda kişinin yüksek motivasyonu, tükenmede benlik kaynaklarını korur. Benlik kaynakları tükendiğinde motivasyon yeterli durumda değildir bu yüzden tükenme durumundaki kişilerde içsel eğilimler ve güdüler daha net gözlenir ve daha büyük davranışsal farklılıklar oluşur. Benlik tükenmesi durumunda sıkı kontrol altındaki dürtülerin önündeki engeller güçsüzleşir ve bunun sonucunda istenmeyen davranışlar ortaya çıkabilir (Baumeister ve ark., 2006). Yani öz denetim sıklıkla toplumun onayladığı ortak kabule göre davranmayı sağladığından herkes görece benzer davranışlar sergilerken ego tükenmesi öz denetimi azaltarak toplumun onaylamadığı dürtü ve arzuların üzerindeki baskıyı kaldırır ve bireysel farklılıklar görülebilir olmaya başlar.

Tice, Baumeister, Shmueli ve Muraven (2007), benlik tükenmesine karşı koruyucu olabilecek başka bir etken olarak duygu durumuna dikkat çekmektedirler. Yapmış oldukları çalışmada, benlik düzenleme gerektiren dört ayrı tükenme durumunun ardından katılımcıların bir kısmında olumlu duygulanım oluşturmaya çalışmışlardır. Bunun için komik bir video veya sürpriz hediye sunma gibi farklı durumlardan faydalanmışlardır. Sonrasında birinci benlik düzenleme durumundan ilgisiz olan benlik düzenleme isteyen başka bir görev tüm katılımcılara verilmiştir. Dört farklı tükenme durumunda da iki görev arasında olumlu duygulanım oluşturulan katılımcıların oluşturulmayanlara göre ikinci 
görevde daha başarılı oldukları görülmüştür. Araştırmacılar, duygu durumunun benlik kaynaklarını yenilemekten ziyade benlik tükenmesine karşı bir güçlendirici olabileceğini belirtmiş̧lerdir. Başka bir çalışmada ise duygu kontrolünde öze yansıtılmış motivasyona sahip bireyler, benlik tükenmesine karşı daha dirençli bulunmuştur (Helvacı, 2010).

Bahsedilen tüm bu benlik tükenmesinin etkisini azaltan motivasyon ya da duygu durum gibi bir takım düzenleyici ya da aracı değişkenlerin varlığı ile aradaki çatışmayı gidermek için Inzlicht ve Schmeichel (2012) süreç modelini önermişlerdir. Modele göre birinci zamandaki öz denetim çabasının ikinci zamandaki çabayı azaltmasının nedeni birinci zamanda motivasyonda meydana gelen değişikliğe bağlı olarak ikinci zamanda dikkatte meydana gelen değişikliktir. Buna göre toplumsal doğrular ya da yapılması gereken doğrultusunda dürtülerini bastıran biri için motivasyonda bir değişiklik olur ve dürtülerin tatminine doğru bir kayma oluşur. Buna bağlı olarak ikinci zamanda dürtülerin bastırılması ipuçlarından çok içsel tatmin ve ödül ipuçlarına doğru dikkatte bir kayma meydana gelir. Inzlicht, Schmeichel ve Macrae (2014) bu doğrultuda benlik tükenmesinin motivasyon, dikkat ve duygudaki değişimlerle yönetilebileceğini vurgulamışlardır. Ona göre benlik düzenlemede kişinin başarısız olmasının nedeni göreve verilen öncelikle ilgili bir durumdur. İstenmeyen ve olumsuz olarak nitelendirilen hedefteki motivasyon "yapılması gereken" değil de "istenilen" olarak yenilendiğinde dikkat ve duyguda da değişim beraberinde gelecektir. Bu sayede bireyin göreve yönelik çabası da artacak ve tükenme de ortadan kalkacaktır.

\section{Çocuklarda Benlik Kaynaklarında Tükenmenin Sonuçları}

Benlik düzenleme becerisinin düşük olması, birey ve toplum için birçok olumsuzluk doğurur. Benlik kaynaklarında tükenme olması ise benlik düzenleme becerisi kullanmayı gerektiren başka alanları da olumsuz etkileyeceğinden farklı sorunların nedeni olabilir. Benlik kaynaklarında tükenme, bilişsel performansta azalma, daha fazla kaygı, daha az keyif alma, bilişsel görevlerde erken pes etme (Gissubel, Beiramar ve Freire, 2018) yalancllı̆̆ algılamada bozulma (Reinhard, Scharmach ve Stahlberg, 2013), hedefe bağlılığın azalması (Wang, Tao, Fan, Gao ve Wei, 2015), düşük öz-yeterlilik (Chow, Hui ve Lau, 2015) gibi birçok bilişsel, duygusal, davranışsal ya da motivasyonel sorunla ilişkilidir.

$\mathrm{Bu}$ alandaki çalışmalar sıklıkla ergen ya da genç yetişkin yaş aralığındaki üniversite öğrencileri ile yürütülmektedir. Bu çalışmalardan elde edilen bulgular benlik düzenleme ile riskli davranışlarda bulunma arasında ilişki olduğu yönündedir (Örn. Magar, Phillips ve Hosie, 2008). Fischer, Kastenmüller ve Asal (2012) benlik düzenleme kaynaklarının risk alma üzerine olan etkisini incelemek için yaptıkları çalışmada benlik tükenmesi durumundaki katılımcıların daha yüksek düzeyde heyecan arayışına sahip olduklarını ve yapılan sürüş testinde daha fazla riskli araba kullanımına eğilim gösterdiklerini, bilişsel olarak yorgun hissettiklerini ve bundan dolayı da riskli davranışta bulunma olasılıklarının yüksek olduğunu bulmuşlardır. Risk alma davranışında kullanılan bilgisayar simülasyonu olan Balon Analog Risk Testinin kullanıldığı bir başka çalışmada ise önceki benlik düzenleme, sonraki benlik düzenleme gerektiren eylemde geçici olarak performansı azaltmış ve risk alma davranışı artmıştır (Freeman ve Muraven, 2010). Bunun yanında risk alma ile ilişkilendirilen bir faktör de dopamin seviyesidir. (Kohno ve ark., 2015). Dopamin ve benlik tükenme arasındaki ilişkiyi konu alan bir araştırma orta seviyede dopaminin benlik tükenme etkisi karşısında koruyucu olabileceğini bildirmiştir (Dang, Xiao, Liu, Jiang ve Mao, 2016). 
Bir başkasının bakışından bir durumu anlayabilme yetisi olan bakış açısı alma gibi toplum açısından faydalı davranışlar benlik düzenleme kaynağında tükenme varsa daha az gözlenir. Fennis (2011) yaptığı çalışmada bakış açısı alabilenlerin yardım etmeye daha istekli olduğunu ve yardım etmeye daha fazla zaman ayırdığını göstermiştir. Ancak bu durum benlik kaynakları yeterli olduğunda ortaya çıkmıştır. Toplum yanlısı davranışlar da benlik tükenmesi durumunda azalmaktadır. Bir araştırmada katılımcılar kendilerinin yararına ve başkalarının yararına olan durumlarla ilgili bir ikilemde bırakılmıştır. Benlik tükenmesi durumu toplum yanlısı davranışlara karşı tutumda bir azaltma oluşturmamış ancak başkalarına yardım etme sırasında kişisel isteklerini bastırma yeteneğini bozmuş ve toplum yanlısı davranış da azalmıştır (Osgood ve Muraven, 2015).

Benlik düzenleme ile ilişkili konulardan birisi de saldırganlıktır (Denson, DeWall ve Finkel, 2012). Bu beceri depresyon, anksiyete, sosyal kaygı, somatik şikayetler ve travma sonrası stres gibi içselleştirilmiş ve dikkat sorunlarıi hiperaktivite, öfke kontrol sorunları, saldırganlık, karşıt olma bozuklığu, antisosyal davranışlar gibi dışsallaştırılmış davranış problemleri (Doan, Fuller-Rowell ve Evans, 2012; Flores, Caqueo-Urízar, Ramírez, Arancio ve Cofré, 2020) saldırgan gençlerde uyum sorunları üzerinde (White, Jarrett ve Ollendick, 2013) etkilidir. Bir çalışma sonucunda katılımcılar hakarete uğradıklarında ve benlik kaynaklarında tükenme durumunda saldırgan davranışlarda artış görülmüştür. Araştırmacılara göre çalı̧̧madaki tükenme saldırganlıkla ilgili yeni bir dürtü oluşturmaz ancak kişide hâlihazırda bulunan ve sosyal normlar tarafından idare edilen saldırganlıkla ilgili dürtülerinin önündeki setleri kaldırır ve saldırganca davranış ortaya çıkar. Çalışmanın başka bir sonucuna göre ise benlik düzenleme becerisi düşük olanların yüksek olanlara göre saldırgan tepki verme niyetini daha çok belirtmiş olmalarıdır (DeWall, Baumeister, Stillman ve Gailliot, 2007). Üç deney tasarımı ile benlik tükenmesinin saldırganlığa etkisinin incelendiği bir başka çalışmada da tüm deneylerin sonucunda benlik tükenmesi durumundaki katılımcılar, kontrol koşulundakilere göre eleştirel ve aşağılayıcı konuşmaya karşı daha saldırgan davranmışlardır (Stucke ve Baumeister, 2006).

Diğer yandan alan yazınında benlik tükenmesinin çocuklardaki etkileri ile ilgili yürütülen araştırmalar oldukça kısıtlıdır. Bununla birlikte bu az sayıdaki çalışmalardan elde edilen bulgular da gelişimsel süreci doğrular nitelikte yetişkin örneklemlerden elde edilenlerle benzer sonuçlar bildirmektedir. Örneğin, Gunzerhouser ve von Suchodoletz (2014) okul öncesi çocuklar ile yürüttüğü çalışmalarında duygusal tepkileri bastırmanın benlik düzenleme kaynakları (tükenme) ve sözel bilgi (müdahale) üzerindeki bilişsel sonuçlarına odaklanmışlardır. Katılımcı çocuklara üzücü ve komik sahneleri olan bir film izletilmiş, ardından deney grubuna duygu düzenleme talimatları verilerek duygularını bastırmaları istenmiştir. Araştırmanın sonucunda duygularını bastıran deney grubundaki çocukların kontrol grubundaki çocuklara göre sonraki benlik düzenleme görevinde daha düşük performans gösterdiği ortaya çıkmış yani benlik kaynaklarında tükenme görülmüştür. Ancak sözel bellekte herhangi bir bozulma oluşmamıştır.

Oeri ve Roebers'in (2020) deneysel araştırmalarında yaklaşık 5 yaşındaki anaokulu çocuklarında hayal kırıklığının ego tükenmesi üzerindeki etkileri bilişsel performans ve davranışsal tepkilere göre incelenmiştir. Çocukların bir kısmına 4 oyuncak gösterilmiş, çocuklar bunları sıralamış, en çok beğendiklerini ve en az beğendiklerini göstermişlerdir. Ardından bir labirent bulmacası verilmiştir. Çözdükten sonra 4 karttan biri seçtirilmiş ve kartta çıkan oyuncak çocuğa verilmiştir. Hileli bir şekilde çocuğun en az istediği oyuncak 
verilerek hayal kırıklığ1 oluşturulmuştur. İstemediği oyuncağı alan çocuğun sözel veya davranışsal tepkilerine bakılmıştır. Kontrol grubundaki çocuklar ise 4 tane zarı büyükten küçüğe dizmiş ardından aynı labirent bulmacasını çözmüştür. İstemediği oyuncağı alan çocuklardan olumlu duygu ifade edenlerin (yani hayal kırıklıklarını bastıranların) bilişsel beceri gerektiren görevdeki performansinda bozulma olurken, olumsuz duygu ifade eden veya tepki göstermeyen çocukların görev performansında herhangi bir bozulma görülmemiştir. Araştırmacılara göre hayal kırıklığını olumlu duygular ile bastırmaya çalışmak Gunzerhouser ve von Suchodoletz'in çalışmasındaki (2014) gibi duyguları bastırmanın bir sonucu olarak performansta düşüşle sonuçlanmıştır.

Bulunulan toplumda farklı ırktan olma nedeniyle olumsuz davranışlara maruz kalma birçok ülkede olduğu gibi Türkiye'de de artan sorunlardan birisidir. Özellikle Türkiye'de Suriyeli çocuklar Türk öğrenciler tarafından dışlanma, dalga geçme, lakap takma gibi farklı davranışlarla karşılaşmakta ve bu okul iklimine olumsuz yansımaktadır (Altıntaş, 2018; Yüce, 2018). Ayrıca dışlanma sadece dışlanan bireyi değil dışlayan kişiyi de etkiler. Ciarocco, Sommer ve Baumeister (2001) yaptıkları araştırmada başkalarını dışlamanın kişilerin benlik kaynaklarında tükenme oluşturduğu sonucuna ulaşmışlardır. Bireylerin ırka dayalı karşılaştı̆̆ damgalanma ile baş edebilmesi ise bir güç yani benlik düzenleme ile sağlanır. Inzlicht, McKay ve Aronson'ın çalışmalarında (2006), damgalanmanın benliği tükettiği ve benlik düzenleme ile ilgili başka alanlarda da sorunlara sebebiyet verdiği bulunmuştur. Irkı ile ilgili damgalanma yaşayan öğrenciler, kendi öğrenmelerini düzenlemede de sorunlar bildirmişlerdir. Bunun yanında, farklı alanlardaki tükenme nedeniyle bilgi edinmenin ve ders çalışmanın bozulması gibi durumlar da akademik başarıyı olumsuz etkileyebilir (Englert ve Bertrams, 2017). Benlik tükenmesi yaşayan öğrenciler konsantrasyon kaybı, akademik performansın kötüleşmesi, ödev teslim tarihlerine uyamama ya da okul görevlerinden kopma gibi sorunlarla karşı karşıya kalabilirler (Englert, Zavery ve Bertrams, 2017).

3-4 yaşlarında (Peverill, Garon, Brown ve Moore, 2017) ve 4-5 yaşlarında (Powell ve Carey, 2017) çocuklarla yapılan çalışmalarda da benlik kaynaklarında tükenmeye ilişkin kanıtlar bulunmuştur. Yapılan araştırmalara göre çocuklarda duyguları bastırmanın benlik kaynaklarına etkisi olabilir. Bununla birlikte bu alanda çocuklarda benlik tükenmesinin neden ve sonuçlarını inceleyen araştırmalara ihtiyaç duyulmaktadır.

Bazı çalışmalarda benlik düzenleme isteyen sonraki görevde bir performans düşüşü görülmemiştir (örn., Çiffiliz-Kınay, 2015; Lurquin ve ark., 2016; Montuoro, 2017). Benlik kaynaklarında tükenme bulmayan araştırmacıların bir kısmı sonucun kültürel koşullar gibi durumlardan kaynaklı olabileceğini belirtirken (örn., Çiffiliz-Kınay, 2015) bazıları da benlik tükenmesinin benlik düzenleme gerektiren yeni duruma uyum şoku ile ilgili bir durum olabileceğini (örn., Montuoro, 2017) ifade etmiştir. Ayrıca Lurquin ve arkadaşlarının (2016) ön kayıtlı çalışmalarının ego tükenmesi denencesini desteklememesi yöntemsel bazı sorunların olabileceğini düşündürmektedir. Bu doğrultuda yazarlar şeffaf araştırma sürecini sağlamak adına ön kayıtlı çalışmalarla konunun daha fazla araştırılmasına gereksinim duyulduğunu düşünmektedirler. Benlik tükenmesi ile ilgili tartışmalar günümüzde devam etmekte ve model sorgulanmaktadır. 


\section{SONUÇ}

Gündelik dilde irade olarak sıklıkla andığımız ve kendi üzerimizdeki bilinçli denetimimizi de kapsayan benlik düzenleme olgusu insan yaşamının her döneminde etkili ve önemli bir özelliktir. Bu özellik ile insan bir anlamda kendini insan kılan niteliklere sahip olur. Ahlaklı bir yaşam sürmekten iyi ilişkiler kurmaya, okula uyum sağlamaktan akademik başarıya ve iş hayatında iyi bir kariyere kadar hayatımızın çeşitli dönemlerindeki birçok olumlu sonuç başarılı benlik düzenleme gerektirmektedir. Benlik düzenleme ise yaşamın ilk yıllarından itibaren gelişmeye başlayan bir özellik olduğundan sürecin iyi anlaşılması ve benlik düzenleme kapasitesi yüksek bireyleri ayrıt eden gelişimsel etkenlerin tespit edilmesi oldukça önemlidir.

Bu çalışmada benlik düzenleme kavramının tasviri ile başlanarak benlik düzenleme gelişimine özet bir bakış sunulmuş ve benlik düzenleme başarısızlıklarına odaklanan temel bir kuramın gelişimsel seyir üzerinde aydınlatılması amaçlanmıştır. Benlik düzenleme becerisi ile ilgili Türkiye'de okullarda yapılan çalışmalar mevcutken çiftler arası ilişkiler anlamında ve kariyer gelişimi konusunda çalışmalara ihtiyaç duyulmaktadır ve sınırlı kaynak kuramı yetişkinlerle ilgili yurt dışı çalışmalarda oldukça popüler olmasına karşın çocuklarda yeterince çalışmaya rastlanmamaktadır. Ayrıca benlik tükenmesi ile ilgili çalışmalar daha önce de belirtildiği gibi, Türkiye'de yok denecek kadar azdır. Diğer yandan yukarıda değinilen tartışmalı sonuçlar modelle ilgili bir takım değişiklik önerilerini ya da modelin daha titiz olarak ele alındığı çalışmaları gerekli kılmaktadır. Dünyada ve Türkiye'de bu alanda yürütülmüş çalışmalara yer vererek benlik düzenleme gelişimi ve sınırlı kaynak modeli hakkında konuyu gelişimsel bağlamda ele almayı hedefleyen bu derleme çalışması ile alan yazınını çocuklardaki benlik düzenleme başarısızlıklarının nedenlerini araştırmaya teşvik etmek amaçlanmıştır. Böylelikle söz konusu kapasitenin gelişimi ve benlik düzenleme başarısızlıklarının önlenmesi noktasında hazırlanacak müdahale programları daha aydınlatıcı rehberlere sahip olabilir.

Bu doğrultuda yürütülecek gelecek çalışmalarda benlik düzenleme ile olumlu ya da olumsuz birtakım sonuçlar arasındaki bağlantıyı etkileyen olası değişkenlerin araştırılması önemlidir. Ayrıca daha önce de değinildiği gibi ön kayıtlı çalışmaların eksikliği, mevcut bulguların üzerindeki tartışmayı gidermek ve yazını sağlam bir zemine oturmak açısından dikkate alınması gereken bir ihtiyacı işaret etmektedir.

\section{SUMMARY}

People are motivated to enhance the quality of their lives, regardless of the situation that they are in. Accordingly, they set new goals, make choices and act in line with these goals or choices. Individuals with high self-regulation can manage their impulses, delay their gratification, control their emotions and thoughts to reach their goals from early childhood. Self-regulation increases awareness about the results of the behavior, so it is associated with many positive outcomes such as academic success, less externalizing behaviors, fulfilling responsibilities, having healthy close relationships, and avoiding risky behaviors. In the development of self-regulation, familial effects have a crucial role. The family influences self-regulation by supporting self-regulative capacities from the first year of life as well as via genetics. Especially, early childhood is important for the role of child rearing. The supportive parental attitudes such as recognizing the child's choices, accepting her/his feelings, and encouraging her/his autonomy positively affects the development of

SEFAD, 2021; (45): 375-400 
self-regulation (Moilanen, Padilla-Walker and Blaacker, 2018). Additionally, the child's relationships and time spent playing with his/her peers affect the development of selfregulation. Games, which provide the opportunity to try out the roles in life, are instructive to control impulse as they contain rules. The child also learns to choose behaviors because he/she is free in the game (Savina, 2014). On the other hand, when it comes to self-regulation failure, the developmental process should not be the only thing that comes to mind. Can the level of self-regulation also change from one situation to another? To be more precise, do sequential self-regulative tasks exhaust the individual's resources? According to the strength model of self- regulation (the limited resource model; Baumeister, Bratslavsky, Muraven, and Tice, 1998; Baumeister and Heatherton, 1996; Baumeister, Vohs, and Tice, 2007), even if the self-regulation skill is high, the first task will exhaust the limited resource temporarily and a performance decrease called "ego depletion" will be observed in the next task. Performance decline may also bring along problems such as more anxiety, giving up early in the task, less pleasure, impaired goal commitment, risky behaviors, and aggression. In short, according to the theory, self-regulation is governed by a limited resource, and recovering of self-regulation capacity needs time like muscles that run out of strength as they get tired. The limited resource concept also brought with it the question of what this resource is. Initially, although glucose was thought to be one of the forces feeding the resource, this thesis was rejected in time due to inconsistent research results (Baumeister, 2018). Current research points to the role of motivation and mood. However, while some studies (e.g. Baumeister and Vohs, 2007; Muraven and Slessareva, 2003) emphasize that the factors in question can compensate for the depletion of ego resources, some (e.g. Inzlicht and Schmeichel, 2012; Schmeichel and Macrae, 2014) claim that giving priority to one of the tasks, lack of motivation or attention are the direct cause of performance decline. This study aims to review self-regulation, an important capacity that helps to organize human life, and its development from childhood. Beyond that, we hope to increase the number of developmental studies on the strength model. There is an important gap in the literature regarding the model in terms of early childhood.

Makale Bilgileri

Etik Kurul Karar:

Katılımo Rızası:

Mali Destek:

Çıkar Çatışması:

Telif Haklari:

Article Information

Ethics Committee Approval: Informed Consent:

Financial Support:

Conflict of Interest:

Copyrights:
Etik Kurul Kararından muaftır.

Katılımcı Yok

Çalışma için herhangi bir kurum ve projeden mali destek alınmamıştır.

Çalışmada kişiler ve kurumlar arası çıkar çatışması bulunmamaktadır.

Telif hakkına sebep olacak bir materyal kullanılmamıştır.
Exempt from the Ethics Committee Decision.

No participant

No financial support from any institution or project.

No conflict of interest.

No material subject to copyright is included. 


\section{KAYNAKÇA}

Adagideli, F. H. (2018). Okul öncesi çocuklarının ilkokula hazır bulunuşluklarının yordayıcısı olarak öz-düzenleme becerilerinin incelenmesi (Yayınlanmamış Doktora Tezi). Marmara Üniversitesi, İstanbul.

Alçay, E. S. (2019). Ergenlerde problemli internet kullanımı ile bilinçli farkındalık ve öz düzenleme arasındaki ilişkilerin incelenmesi (Yayımlanmamış Yüksek Lisans Tezi). Akdeniz Üniversitesi Eğitim Bilimler Enstitüsü, Antalya.

Aldan-Karademir, Ç., Deveci, Ö. ve Çaylı, B. (2018). Ortaokul öğrencilerinin özdüzenlemeleri ve akademik öz-yeterliklerinin incelenmesi. E-Kafkas Eğitim Araştırmaları Dergisi, 5(3), 14-29. doi:10.30900/kafkasegt.446793

Altıntaş, M. E. (2018). DKAB Öğretmenlerine Göre Suriyeli Çocukların Devlet Okullarında Karşılaştıkları Sorunlar (Nitel Bir Araştırma). Marife Dini Araştırmalar Dergisi, 18(2), 469499.

Anderson, S. E. ve Keim, S. A. (2016). Parent-child interaction, self-regulation, and obesity prevention in early childhood. Current Obesity Reports, 5(2), 192-200. doi:10.1007/s13679016-0208-9

Anokhin, A. P., Golosheykin, S., Grant, J. D. ve Heath, A. C. (2011). Heritability of delay discounting in adolescence: a longitudinal twin study. Behavior genetics, 41(2), 175-183. Doi:10.1007/s10519-010-9384-7

Astarlar, F. (2019). Okul öncesi eğitime devam eden 4-6 yaş çocuklarının öz-düzenleme becerilerinin izlenmesi (Yüksek Lisans Tezi). Pamukkale Üniversitesi, Denizli.

Atmaca, R. N. (2019). Okul öncesi dönem çocuklarmın öz düzenleme ve sosyal beceri düzeyleri ile annelerin empatik becerileri arasındaki ilişkinin incelenmesi (Yayımlanmamış Yüksek Lisans Tezi). Gazi Üniversitesi Eğitim Bilimleri Enstitüsü, Ankara.

Bandura, A. (1977). Self-efficacy: Toward a unifying theory of behavioral change. Psychological Review, 84(2), 191-215. doi:10.1037/0033-295X.84.2.191

Bandura, A. (1978). Reflections on self-efficacy. Advances in Behaviour Research and Therapy, 1(4), 237-269. doi:10.1016/0146-6402(78)90012-7

Bandura, A. (1983). Self-efficacy determinants of anticipated fears and calamities. Journal of Personality and Social Psychology, 45(2), 464-469. doi:10.1037/0022-3514.45.2.464

Bandura, A. (1991). Social cognitive theory of self-regulation. Organizational Behavior and Human Decision Processes, 50(2), 248-287. doi:10.1016/0749-5978(91)90022-L

Bandura, A. (1994). Self-efficacy. V. S. Ramachaudran (Ed.), Encyclopedia of human behavior içinde (Cilt 4, s. 71-81). New York: Academic Press.

Bandura, A. (1995). Self-efficacy in changing societies. New York: Cambridge University Press.

Bandura, A. (1997). Self-efficacy: the exercise of control. New York: Freeman.

Bandura, A., Caprara, G. V., Barbaranelli, C., Gerbino, M. ve Pastorelli, C. (2003). Role of affective self-regulatory efficacy in diverse spheres of psychosocial functioning. Child Development, 74(3), 769-782. doi:10.1111/1467-8624.00567

SEFAD, 2021; (45): 375-400 
Barnes, J. C., Boutwell, B. B., Beaver, K. M. ve Gibson, C. L. (2013). Analyzing the origins of childhood externalizing behavioral problems. Developmental Psychology, 49(12), 22722284. Doi: $10.1037 / \mathrm{a} 0032061$

Baumeister, R. F. (2002). Ego depletion and self-control failure: An energy model of the self's executive function. Self and Identity, 1(2), 129-136. doi:10.1080/152988602317319302

Baumeister, R. F. (2003). Ego depletion and self-regulation failure: A resource model of selfcontrol. Alcoholism: Clinical and Experimental Research, 27(2), 281-284. doi:10.1097/01.ALC.0000060879.61384.A4

Baumeister, R. F. (2018). Self-regulation and self-control: Selected works of Roy F. Baumeister, New York: Routledge.

Baumeister, R. F. ve Alquist, J. L. (2009). Is there a downside to good self-control?. Self and Identity, 8(2-3), 115-130. doi:10.1080/15298860802501474

Baumeister, R. F. ve Heatherton, T. F. (1996). Self-regulation failure: An overview. Psychological Inquiry, 7(1), 1-15. doi:10.1207/s15327965pli0701_1

Baumeister, R. F. ve Vohs, K. D. (2007). Self-Regulation, ego depletion, and motivation. Social and Personality Psychology Compass, 1(1), 115-128. doi:10.1111/j.1751-9004.2007.00001.x

Baumeister, R. F., Bratslavsky, E., Muraven, M. ve Tice, D. M. (1998). Ego depletion: Is the active self a limited resource? Journal of Personality And Social Psychology, 74(5), 12521265. doi:10.1037/0022-3514.74.5.1252

Baumeister, R. F., Gailliot, M., DeWall, C. N. ve Oaten, M. (2006). Self-regulation and personality: How interventions increase regulatory success, and how depletion moderates the effects of traits on behavior. Journal of Personality, 74(6), 1773-1802. doi:10.1111/j.1467-6494.2006.00428.x

Baumeister, R. F., Vohs, K. D. ve Tice, D. M. (2007). The strength model of self-control. Current Directions in Psychological Science, 16(6), 351-355. doi:10.1111/j.14678721.2007.00534.x

Bayındır, D. ve Biber, K. (2019). 60-72 aylık çocukların okula hazır bulunuşluk düzeyleri ile öz düzenleme beceri düzeyleri arasındaki ilişkinin incelenmesi. Kalem Ĕ̆itim ve İnsan Bilimleri Dergisi, 9(1), 135-154.

Bayındır, D. ve Ural, O. (2019). Okul öncesi dönem çocukların öz düzenleme becerilerinin annelerine bağlanma biçimlerine ve annelerin ebeveynlik davranışlarına göre incelenmesi. Kastamonu Education Journal, 27(4), 2597-2608. doi:10.24106/kefdergi.3456

Baysal, A. ve Özgenel, M. (2019). Ortaokul öğrencilerinin bağlanma stilleri ile öz düzenleme düzeyleri arasındaki ilişkinin incelenmesi. Eğitimde Kuram ve Uygulama, 15(2), 142-152. doi:10.17244/eku.507650

Beaver, K. M., Wright, J. P., DeLisi, M. ve Vaughn, M. G. (2008). Genetic influences on the stability of low self-control: Results from a longitudinal sample of twins. Journal of Criminal Justice, 36(6), 478-485. doi:10.1016/j.jcrimjus.2008.09.006 
Berger, A., Kofman, O., Livneh, U. ve Henik, A. (2007). Multidisciplinary perspectives on attention and the development of self-regulation. Progress in Neurobiology, 82(5), 256286. Doi: 10.1016/j.pneurobio.2007.06.004

Boekaerts, M., Pintrich, P.R. ve Zeidner, M. (2000), Handbook of self-regulation. San Diego, CA: Academic Press.

Bronson, M. (2019). Erken çocuklukta öz-düzenleme (E. Sezgin ve M. Kır-Yiğit, Çev.). Ankara: Eğiten Kitap Yayıncılık.

Bukhtawer, N., Muhammad, S. ve Iqbal, A. (2014). Personality traits and self regulation: A comparative study among current, relapse and remitted drug abuse patients. Health, 6(12), 1368-1375. doi:10.4236/health.2014.612168

Bunt, S., ve Hazelwood, Z. J. (2017). Walking the walk, talking the talk: Love languages, selfregulation, and relationship satisfaction. Personal Relationships, 24(2), 280-290. doi: 10.1111/pere. 12182

Chen, X. ve Schmidt, L. A. (2015). Temperament and personality. Handbook of Child Psychology and Developmental Science, 3, 1-49. doi:10.1002/9781118963418.childpsy305

Chow, J. T., Hui, C. M. ve Lau, S. (2015). A depleted mind feels inefficacious: Ego-depletion reduces self-efficacy to exert further self-control. European Journal of Social Psychology, 45(6), 754-768. doi:10.1002/ejsp.2120

Ciarocco, N. J., Sommer, K. L. ve Baumeister, R. F. (2001). Ostracism and ego depletion: The strains of silence. Personality and Social Psychology Bulletin, 27(9), 1156-1163. doi: $10.1177 / 0146167201279008$

Converse, P. D., Pathak, J., DePaul-Haddock, A. M., Gotlib, T., \& Merbedone, M. (2012). Controlling your environment and yourself: Implications for career success. Journal of Vocational Behavior, 80(1), 148-159. doi:10.1016/j.jvb.2011.07.003

Çiffiliz-Kınay G. (2015). Bilişsel, duygusal, dürtüsel ve sosyal alanlardaki benlik kontrolünün benlik kaynaklarının tüketilmesi üzerindeki etkileri (Yayınlanmamış Doktora Tezi), Hacettepe Üniversitesi, Ankara.

Dağgül H. C. (2016). Okul öncesi dönem çocuklarının öz düzenleme becerileri ile ebeveynlerin çocuk yetiştirme stilleri arasındaki ilişkinin incelenmesi (Yüksek Lisans Tezi). Doğu Akdeniz Üniversitesi, Gazimağusa, KKTC.

Dang, J. (2016). Testing the role of glucose in self-control: a meta-analysis. Appetite, 107, 222230. doi:10.1016/j.appet.2016.07.021

Dang, J., Xiao, S., Liu, Y., Jiang, Y. ve Mao, L. (2016). Individual differences in dopamine level modulate the ego depletion effect. International Journal of Psychophysiology, 99, 121124. doi:10.1016/j.ijpsycho.2015.11.013

Demir, M. K. ve Budak, H. (2016). İlkokul dördüncü sınıf öğrencilerinin öz düzenleme, motivasyon, biliş üstü becerileri ile matematik dersi başarılarının arasındaki ilişki. Dokuz Eylül Üniversitesi Buca Ĕ̆itim Fakültesi Dergisi, 41, 30-41.

SEFAD, 2021; (45): 375-400 
Denissen, J. J., van Aken, M. A., Penke, L. ve Wood, D. (2013). Self-regulation underlies temperament and personality: An integrative developmental framework. Child Development Perspectives, 7(4), 255-260. doi: 10.1111/cdep.12050

Denson, T. F., DeWall, C. N. ve Finkel, E. J. (2012). Self-control and aggression. Current Directions in Psychological Science, 21(1), 20-25. doi:10.1177/0963721411429451

DeWall, C. N., Baumeister, R. F., Stillman, T. F. ve Gailliot, M. T. (2007). Violence restrained: Effects of self-regulation and its depletion on aggression. Journal of Experimental Social Psychology, 43(1), 62-76. doi:10.1016/j.jesp.2005.12.005

Doan, S. N., Fuller-Rowell, T. E. ve Evans, G. W. (2012). Cumulative risk and adolescent's internalizing and externalizing problems: The mediating roles of maternal responsiveness and self-regulation. Developmental Psychology, 48(6), 1529-1539. doi:10.1037/a0027815

Emre, O., Tarkoçin, S., Temiz, A. ve Ulutaş, A. (2019). 48-62 aylık çocukların öz-düzenleme becerileri ve ebeveynlerin iletişim kurma düzeyleri arasındaki ilişki. İnönü Üniversitesi Uluslararası Sosyal Bilimler Dergisi (INIJOSS), 8(2), 519-528.

Englert, C. ve Bertrams, A. (2017). Ego depletion negatively affects knowledge retrieval in secondary school students. Educational Psychology, 37(9), 1057-1066. doi:10.1080/01443410.2017.1313963

Englert, C., Zavery, A. ve Bertrams, A. (2017). Too exhausted to perform at the highest level? On the importance of self-control strength in educational settings. Frontiers in Psychology, 8, 1-16.

Feng, X., Hooper, E. G. ve Jia, R. (2017). From compliance to self-regulation: Development during early childhood. Social Development, 26(4), 981-995. doi:10.1111/sode.12245

Fennis, B. M. (2011). Can't get over me: Ego depletion attenuates prosocial effects of perspective taking. European Journal of Social Psychology, 41(5), 580-585. doi:10.1002/ejsp.828

Fischer, P., Kastenmüller, A. ve Asal, K. (2012). Ego depletion increases risk-taking. The Journal of Social Psychology, 152(5), 623-638. doi:10.1080/00224545.2012.683894

Flores, J., Caqueo-Urízar, A., Ramírez, C., Arancio, G. ve Cofré, J. P. (2020). Locus of control, self-control, and gender as predictors of internalizing and externalizing problems in children and adolescents in northern chile. Frontiers in Psychology, 11, 1-15. doi:10.3389/fpsyg.2020.02015

Foley, G. M. (2017). Play as regulation. Topics in Language Disorders, 37(3), 241-258. doi:10.1097/TLD.0000000000000129

Fox, E. ve Riconscente, M. (2008). Metacognition and self-regulation in James, Piaget and Vygotsky. Educational Psychology Review, 20(4), 373-389. doi:10.1007/s10648-008-9079-2

Freeman, N. ve Muraven, M. (2010). Self-control depletion leads to increased risk taking. Social Psychological and Personality Science, 1(2), 175-181. doi:10.1177/1948550609360421

Frick, M. A., Forslund, T. ve Brocki, K. C. (2019). Does child verbal ability mediate the relationship between maternal sensitivity and later self-regulation? A longitudinal 
study from infancy to 4 years. Scandinavian Journal of Psychology, 60(2), 97-105. doi:10.1111/sjop.12512

Gailliot, M. T., Baumeister, R. F., DeWall, C. N., Maner, J. K., Plant, E. A., Tice, D. M., ... Schmeichel, B. J. (2007). Self-control relies on glucose as a limited energy source: willpower is more than a metaphor. Journal Of Personality And Social Psychology, 92(2), 325-336. doi:10.1037/0022-3514.92.2.325

Gailliot, M. T., ve Baumeister, R. F. (2007). The physiology of willpower: Linking blood glucose to self-control. Personality And Social Psychology Review, 11(4), 303-327. doi:10.1177/1088868307303030

Gestsdottir, S., Von Suchodoletz, A., Wanless, S. B., Hubert, B., Guimard, P., Birgisdottir, F., ... McClelland, M. (2014). Early behavioral self-regulation, academic achievement, and gender: Longitudinal findings from France, Germany, and Iceland. Applied Developmental Science, 18(2), 90-109. doi:10.1080/10888691.2014.894870

Gissubel, K., Beiramar, A. ve Freire, T. (2018). The ego depletion effect on undergraduate university students: A systematic review. Motivation and Emotion, 42(3), 334-347. doi:10.1007/s11031-018-9686-2

Gunzenhauser, C. ve von Suchodoletz, A. (2014). Preschoolers' use of suppression influences subsequent self-control but does not interfere with verbal memory. Learning and Individual Differences. 32, 219-224. doi:10.1016/j.lindif.2014.03.007

Healey, D. M. ve Halperin, J. M. (2015). Enhancing Neurobehavioral Gains with the Aid of Games and Exercise (ENGAGE): Initial open trial of a novel early intervention fostering the development of preschoolers' self-regulation. Child Neuropsychology, 21(4), 465-480. doi:10.1080/09297049.2014.906567

Helvac1, E. (2010). The impact of perceived parental control on internalization and ego depletion (Yayımlanmamış Yüksek Lisans Tezi), ODTÜ, Ankara.

Hofmann, W., Finkel, E. J., \& Fitzsimons, G. M. (2015). Close relationships and selfregulation: How relationship satisfaction facilitates momentary goal pursuit. Journal of Personality and Social Psychology, 109(3), 434-452. doi:10.1037/pspi0000020

Hossein-Ziyae-Sabonchi, M. (2019). Lise öğrencilerinde problem çözme becerileriyle, öz yeterlik ve öz düzenleme arasındaki ilişkinin incelenmesi (Yayımlanmamış Yüksek Lisans Tezi). Gazi Üniversitesi Eğitim Bilimleri Enstitüsü, Ankara.

Hoyle, R. H. (2010). Handbook of personality and self-regulation. UK: Wiley-Blackwell.

Inzlicht, M. ve Schmeichel, B. J. (2012). What is ego depletion? Toward a mechanistic revision of the resource model of self-control. Perspectives on Psychological Science, 7(5), 450-463.

Inzlicht, M., McKay, L. ve Aronson, J. (2006). Stigma as ego depletion: How being the target of prejudice affects self-control. Psychological Science, 17(3), 262-269. doi:10.1111/j.14679280.2006.01695.x

Inzlicht, M., Schmeichel, B. J. ve Macrae, C. N. (2014). Why self-control seems (but may not be) limited. Trends in Cognitive Sciences, 18(3), 127-133. doi:10.1016/j.tics.2013.12.009

SEFAD, 2021; (45): 375-400 
İleri G. (2019). Okul öncesi dönem çocukların öz düzenleme becerileri ile akran zorbah̆̆ı̆ı maruz kalma düzeyleri arasındaki ilişkinin incelenmesi (Yayımlanmamış Yüksek Lisans Tezi). Gazi Üniversitesi Eğitim Bilimleri Enstitüsü, Ankara.

İvrendi, A. (2016). Choice-driven peer play, self-regulation and number sense. European Early Childhood Education Research Journal, 24(6), 895-906. doi:10.1080/1350293X.2016.1239325

Kanfer, R., Wanberg, C. R. ve Kantrowitz, T. M. (2001). Job search and employment: A personality-motivational analysis and meta-analytic review. Journal of Applied Psychology, 86(5), 837-855. doi:10.1037/0021-9010.86.5.837

Kara, D. (2014). Role of parenting and self-types on international self- and emotion regulation in adolescence (Yayınlanmamış Yüksek Lisans Tezi). Koç Üniversitesi Sosyal Bilimler Enstitüsü, İstanbul.

Karakurt, Ç. (2019). Okul öncesi eğitime devam eden 48-72 aylık çocukların öz düzenleme becerileri ile dil becerileri arasındaki ilişkinin incelenmesi (Yayımlanmamış Yüksek Lisans Tezi). İstanbul Üniversitesi Cerrahpaşa Lisansüstü Eğitim Enstitüsü, İstanbul.

Karoly, P. (1993). Mechanisms of self-regulation: A systems view. Annual Review of Psychology, 44(1), 23-52. doi:10.1146/annurev.ps.44.020193.000323

Kim, S. ve Kochanska, G. (2012). Child temperament moderates effects of parent-child mutuality on self-regulation: A relationship-based path for emotionally negative infants. Child development, 83(4), 1275-1289. doi:10.1111/j.1467-8624.2012.01778.x

Kochanska, G., Coy, K. C. ve Murray, K. T. (2001). The development of self-regulation in the first four years of life. Child Development, 72(4), 1091-1111. doi:10.1111/1467-8624.00336

Kohno, M., Ghahremani, D. G., Morales, A. M., Robertson, C. L., Ishibashi, K., Morgan, A. T., ... ve London, E. D. (2015). Risk-taking behavior: dopamine D2/D3 receptors, feedback, and frontolimbic activity. Cerebral cortex, 25(1), 236-245. doi:10.1093/cercor/bht218

Kopp, C. B. (1982). Antecedents of self-regulation: a developmental perspective. Developmental Psychology, 18(2), 199-214. doi:10.1037/0012-1649.18.2.199

Kopp, C. B. (1989). Regulation of distress and negative emotions: A developmental view. Developmental Psychology, 25(3), 343-354. doi:10.1037/0012-1649.25.3.343

Lange, F. (2015). If ego depletion cannot be studied using identical tasks, it is not ego depletion. Appetite, 84, 325-327. doi:10.1016/j.appet.2014.10.026

Lange, F. ve Eggert, F. (2014). Sweet delusion. Glucose drinks fail to counteract ego depletion. Appetite, 75, 54-63. doi:10.1016/j.appet.2013.12.020

Lange, F., Seer, C., Rapior, M., Rose, J. ve Eggert, F. (2014). Turn it all you want: still no effect of sugar consumption on ego depletion. Journal of European Psychology Students, 5(3), 1-8. doi:10.5334/jeps.cc

Liu, S., Wang, M., Liao, H. ve Shi, J. (2014). Self-regulation during job search: The opposing effects of employment self-efficacy and job search behavior self-efficacy. Journal of Applied Psychology, 99(6), 1159-1172. doi:10.1037/a0036692

Lurquin, J. H., Michaelson, L. E., Barker, J. E., Gustavson, D. E., Von Bastian, C. C., Carruth, N. P. ve Miyake, A. (2016). No evidence of the ego-depletion effect across task 
characteristics and individual differences: A pre-registered study. PLoS ONE, 11(2), e0147770. doi:10.1371/journal.pone.0147770

Mace, F. C., Belfiore, P. J. ve Shea, M. C. (1989). Operant theory and research on selfregulation. B. J. Zimmerman ve D. H. Schunk (Ed.), Self-reguluted learning and academic achievement: Theory, research, and practice içinde (s. 27-50). Springer, New York, NY.

Magar, E. C. E., Phillips, L. H. ve Hosie, J. A. (2008). Self-regulation and risk-taking. Personality and Individual Differences, 45(2), 153-159. doi:10.1016/j.paid.2008.03.014

Mayer, R. E. (1996). Learners as information processors: Legacies and limitations of educational psychology's second. Educational Psychologist, 31(3-4), 151-161. doi:10.1080/00461520.1996.9653263

Mazılı, S. (2019). Ergenlerde akıllı telefon bağımlilı̆̆ııı özdenetim açısından incelenmesi (Yayınlanmamış Yüksek Lisans Tezi), Afyon Kocatepe Üniversitesi, Afyon.

McClelland, M. M. ve Cameron, C. E. (2011). Self-regulation and academic achievement in elementary school children. New Directions for Child and Adolescent Development, 2011(133), 29-44. doi:10.1002/cd.302

McClelland, M. M., ve Wanless, S. B. (2012). Growing up with assets and risks: The importance of self-regulation for academic achievement. Research in Human Development, 9(4), 278-297. doi:10.1080/15427609.2012.729907

Mercan, M. (2019). Okul öncesi eğitim kurumlarına devam eden 5-6 yaş çocuklarının öz düzenleme becerileri ile akademik benlik saygıları ve kişilerarası problem çözme becerileri arasındaki ilişkinin incelenmesi (Yayınlanmamış Yüksek Lisans Tezi). Gazi Üniversitesi Eğitim Bilimleri Enstitüsü, Ankara.

Mischel, W., Shoda, Y. ve Peake, P. K. (1988). The nature of adolescent competencies predicted by preschool delay of gratification. Journal of Personality and Social Psychology, 54(4), 687-696. Doi: 10.1037/0022-3514.54.4.687

Mischel, W., Shoda, Y. ve Rodriguez, M. (1989). Delay of gratification in children. Science, 244(4907), 933-938. Doi: 10.1126/science.2658056

Moilanen, K. L., Padilla-Walker, L. M. ve Blaacker, D. R. (2018). Dimensions of short-term and long-term self-regulation in adolescence: Associations with maternal and paternal parenting and parent-child relationship quality. Journal of Youth and Adolescence, 47(7), 1409-1426. doi:10.1007/s10964-018-0825-6

Molden, D. C., Hui, C. M., Scholer, A. A., Meier, B. P., Noreen, E. E., D'Agostino, P. R. ve Martin, V. (2012). Motivational versus metabolic effects of carbohydrates on self-control. Psychological Science, 23(10), 1137-1144. doi:10.1177/0956797612439069

Montuoro, P. (2017). Failure to replicate ego depletion in the mechanism underlying teacher aggression: a conditional process analysis. Journal of Articles in Support of the Null Hypothesis, 14(1) 1-18.

Muraven, M. ve Baumeister, R. F. (2000). Self-regulation and depletion of limited resources: Does self-control resemble a muscle? Psychological Bulletin, 126(2), 247259. doi:10.1037/0033-2909.126.2.247 
Muraven, M. ve Slessareva, E. (2003). Mechanisms of Self-Control Failure: Motivation and Limited Resources. Personality and Social Psychology Bulletin, 29(7), 894906. doi:10.1177/0146167203029007008

Muraven, M., Tice, D. M. ve Baumeister, R. F. (1998). Self-control as a limited resource: regulatory depletion patterns. Journal of Personality and Social Psychology, 74(3), 774. doi:10.1037/0022-3514.74.3.774

Napolitano, C. M., Hoff, K. A., Ming, C. W. J., Tu, N. ve Rounds, J. (2020). Great expectations: Adolescents' intentional self-regulation predicts career aspiration and expectation consistency. Journal of Vocational Behavior, 80(1), 148-159. doi:10.1016/j.jvb.2020.103423

Nęcka, E., Korona-Golec, K., Hlawacz, T., Nowak, M. ve Gruszka-Gosiewska, A. (2019). The relationship between self-control and temperament: A contribution to self-control definition debate. Current Issues in Personality Psychology, 7(1), 24-31. doi:10.5114/cipp.2019.82922

Oeri, N. ve Roebers, C. M. (2020). Regulating disappointment can impair cognitive performance in kindergarten children: Individual differences in ego depletion. Journal of Experimental Child Psychology, 190, 1-10. doi:10.1016/j.jecp.2019.104728

Orange, C. (1999). Using peer modeling to teach self-regulation. The Journal of Experimental Education, 68(1), 21-39. doi:10.1080/00220979909598492

Osgood, J. M. ve Muraven, M. (2015). Self-control depletion does not diminish attitudes about being prosocial but does diminish prosocial behaviors. Basic and Applied Social Psychology, 37(1), 68-80. doi:10.1080/01973533.2014.996225

Özen, Ö. E. (2016). Lise son sinıf öğrencilerinin öz-düzenleme becerileri ile sınav kaygıları arasındaki ilişkinin incelenmesi (Yayınlanmamış Yüksek Lisans Tezi). Çanakkale Onsekiz Mart Üniversitesi Eğitim Bilimleri Enstitüsü, Çanakkale.

Pazarbaşıı, H. ve Cantez, K. E. (2019). Anaokuluna devam eden 66 ayını doldurmuş çocukların öz düzenleme becerileri ile akran ilişkileri arasındaki ilişkinin incelenmesi. IBAD Sosyal Bilimler Dergisi, (5), 267-283. Doi:10.21733/ibad.624687

Peverill, S., Garon, N., Brown, A. ve Moore, C. (2017). Depleting and motivating selfregulation in preschoolers. Cognitive Development, 44, 116-126. doi:10.1016/j.cogdev.2017.09.005

Powell, L. J. ve Carey, S. (2017). Executive function depletion in children and its impact on theory of mind. Cognition, 164, 150-162. doi:10.1016/j.cognition.2017.03.022

Rawn, C. D. ve Vohs, K. D. (2006). The Importance of Self-Regulation for Interpersonal Functioning. K. D. Vohs ve E. J. Finkel (Ed.) Self and Relationships içinde (s.15-31). New York: The Guilford Press.

Reinhard, M. A., Scharmach, M. ve Stahlberg, D. (2013). Too exhausted to see the truth: Ego depletion and the ability to detect deception. British Journal of Social Psychology, 52(4), 618-630. doi:10.1111/j.2044-8309.2012.02113.x

Savina, E. (2014). Does play promote self-regulation in children?. Early Child Development and Care, 184(11), 1692-1705. Doi:10.1080/03004430.2013.875541 
Schmitt, S. A., McClelland, M. M., Tominey, S. L. ve Acock, A. C. (2015). Strengthening school readiness for Head Start children: Evaluation of a self-regulation intervention. Early Childhood Research Quarterly, 30, 20-31. Doi:10.1016/j.ecresq.2014.08.001

Selçuk, O. C. (2019). İnternet bağımlılığı için risk faktörleri: öz düzenleme yetersizliği ve boş zaman can sıkıntısı (Yayımlanmamış Yüksek Lisans Tezi), Aydın Adnan Menderes Üniversitesi, Aydin.

Sohn, B., Buchanan, A., Heo, K. H. ve Lee, J. J. (2019). Explanatory effects of young childhood caregiving environment, child's pro-social behavior, and child self- regulation skills on adolescent problem behavior. Children and Youth Services Review, 100, 298-303. Doi:10.1016/j.childyouth.2019.03.016

Sop, A. (2016). Ebeveyn tutumları, davranış problemleri ve okula hazır bulunuşluk arasındaki ilişkinin öz düzenlemenin aracilı etkisi ile incelenmesi (Yayınlanmamış Doktora Tezi), Hacettepe Üniversitesi, Ankara.

Stucke, T. S. ve Baumeister, R. F. (2006). Ego depletion and aggressive behavior: Is the inhibition of aggression a limited resource?. European Journal of Social Psychology, 36(1), 1-13. doi:10.1002/ejsp.285

Şamlı, H. Ö. (2019). Okul öncesi dönemdeki çocukların öz düzenleme becerileri ile okul olgunluk düzeyleri arasındaki ilişkinin incelenmesi (Yayımlanmamış Yüksek Lisans Tezi). Gazi Üniversitesi Eğitim Bilimleri Enstitüsü, Ankara.

Şepitci-Sarıbaş, M. ve Gültekin-Akduman, G. (2019). 5-6 yaş çocuklarının öz düzenleme becerilerinin okul uyumu ile ilişkisi. Journal of International Social Research, 12(63), 862883. doi:10.17719/jisr.2019.3283

Tangney, J. P., Baumeister, R. F. ve Boone, A. L. (2004). High self-control predicts good adjustment, less pathology, better grades, and interpersonal success. Journal of Personality, 72(2), 271-324. Doi:10.1111/j.0022-3506.2004.00263.x

Tekin, H. (2018). Erken çocukluk döneminde öz düzenleme becerileri ile ilkokula hazırbulunuşluk arasındaki iliş̧kinin incelenmesi (Yayımlanmamış Yüksek Lisans Tezi). Aydın Adnan Menderes Üniversitesi Sosyal Bilimler Enstitüsü, Aydın.

Temiz, A. (2019). Okul öncesi dönemde davranısssal öz-düzenleme becerilerinin çocuğa ve aileye ilişkin değişkenler ile ebeveyn tutumları açısından incelenmesi (Yayımlanmamış Yüksek Lisans Tezi). Gazi Üniversitesi Eğitim Bilimleri Enstitüsü, Ankara.

Tice, D. M., Baumeister, R. F., Shmueli, D. ve Muraven, M. (2007). Restoring the self: Positive affect helps improve self-regulation following ego depletion. Journal of Experimental Social Psychology, 43(3), 379-384. doi:10.1016/j.jesp.2006.05.007

Tozduman-Yaralı, K. ve Güngör-Aytar, F. A. (2017). Okul öncesi dönem çocuklarının davranışlarının öz düzenleme becerileri yönünden incelenmesi. Mersin Üniversitesi Eğitim Fakültesi Dergisi. 13(3), 856-870. doi:10.17860/mersinefd.291209

Tuzcuoğlu, N., Efe-Azkeskin, K., İlçi-Küsmüş, G. ve Cengiz, Ö. (2019). Okul öncesi dönem çocuklarının öz düzenleme becerileri ile benlik algıları arasındaki ilişkisinin incelenmesi. IBAD Sosyal Bilimler Dergisi, 607-623. doi:10.21733/ibad.613920

SEFAD, 2021; (45): 375-400 
Ursache, A., Blair, C. ve Raver, C. C. (2012). The promotion of self-regulation as a means of enhancing school readiness and early achievement in children at risk for school failure. Child Development Perspectives, 6(2), 122-128. doi:10.1111/j.1750-8606.2011.00209.x

Uykan, E. ve Akkaynak, M. (2019). Ebeveyn tutumları ile çocukların öz düzenlemeleri arasındaki ilişkinin incelenmesi. Akademik Tarih ve Düşünce Dergisi, 6(3), 1620-1644.

Wang, L., Tao, T., Fan, C., Gao, W. ve Wei, C. (2015). The influence of chronic ego depletion on goal adherence: An experience sampling study. PLoS ONE, 10(11), e0142220. doi:10.1371/journal.pone.0142220

Watson, D. L. ve Tharp, R. G. (2014). Self-directed behavior: self-modification for personal adjustment, Belmont, CA: Wadsworth Cengage Learning.

White, B. A., Jarrett, M. A. ve Ollendick, T. H. (2013). Self-regulation deficits explain the link between reactive aggression and internalizing and externalizing behavior problems in children. Journal of Psychopathology and Behavioral Assessment, 35(1), 1-9. doi:10.1007/s10862-012-9310-9

Whitebread, D., Coltman, P., Jameson, H. ve Lander, R. (2009). Play, cognition and selfregulation: What exactly are children learning when they learn through play? Educational and Child Psychology, 26(2), 40-52.

Willis, E. ve Dinehart, L. H. (2014). Contemplative practices in early childhood: implications for self-regulation skills and school readiness. Early Child Development and Care, 184(4), 487-499. doi:10.1080/03004430.2013.804069

Wills, T. A., DuHamel, K. ve Vaccaro, D. (1995). Activity and mood temperament as predictors of adolescent substance use: Test of a self-regulation mediational model. Journal of Personality and Social Psychology, 68(5), 901-916.

Yüce, E. (2018). Geçici koruma altında bulunan Suriyeli öğrencilerin okula uyumları (Yayınlanmamış Yüksek Lisans Tezi). Hacettepe Üniversitesi Eğitim Bilimleri Enstitüsü, Ankara.

Zahn, D., Tug, S., Wenzel, M., Simon, P. ve Kubiak, T. (2016). Glucose metabolism and selfregulation-Is insulin resistance a valid proxy of self-control?. Personality and Individual Differences, 99, 38-45. doi:10.1016/j.paid.2016.04.070

Zeinali, A., Sharifi, H., Enayati, M., Asgari, P. ve Pasha, G. (2011). The mediational pathway among parenting styles, attachment styles and self-regulation with addiction susceptibility of adolescents. Journal of Research in Medical Sciences, 16(9), 1105-1121.

Zimmerman, B. J. (1989). A social cognitive view of self-regulated academic learning. Journal of Educational Psychology, 81(3), 329-339. doi:10.1037/0022-0663.81.3.329

Zimmerman, B. J. (2000). Attainment of self-regulation: A social cognitive perspective. M. Boekaerts, P.R., Pintrich, ve M. Zeidner (Ed.), Handbook of self-regulation içinde (s. 13-39). San Diego, CA: Academic Press. 